\title{
Excavations at the site of Vasino, Lautem District, Timor-Leste
}

\author{
Sally Brockwell, Sue 0'Connor, Jack N. Fenner, Andrew McWilliam, \\ Noel Amano Jr, Philip J. Piper, David Bulbeck, Mirani Litster, \\ Rose Whitau, Jack 0'Connor-Veth, Tim Maloney, Judith Cameron, \\ Richard C. Willan and William R. Dickinson
}

\section{Introduction}

This chapter explores the archaeology and ethnohistory of one of the distinctive fortified settlements in the eastern part of Timor-Leste. In 2009, a team from The Australian National University (ANU), together with local people, partially excavated the site of Vasino, located close to the north coast of Timor-Leste, above the modern village of Moro-Parlamento (Figure 4.1). The site had been fortified with large stone walls and the aim was to provide more data on when, how and why these fortifications were used in the region. Two related questions guided the research. First, when was the main period of fort construction initiated? Secondly, what were the prevailing environmental and social conditions of those times?

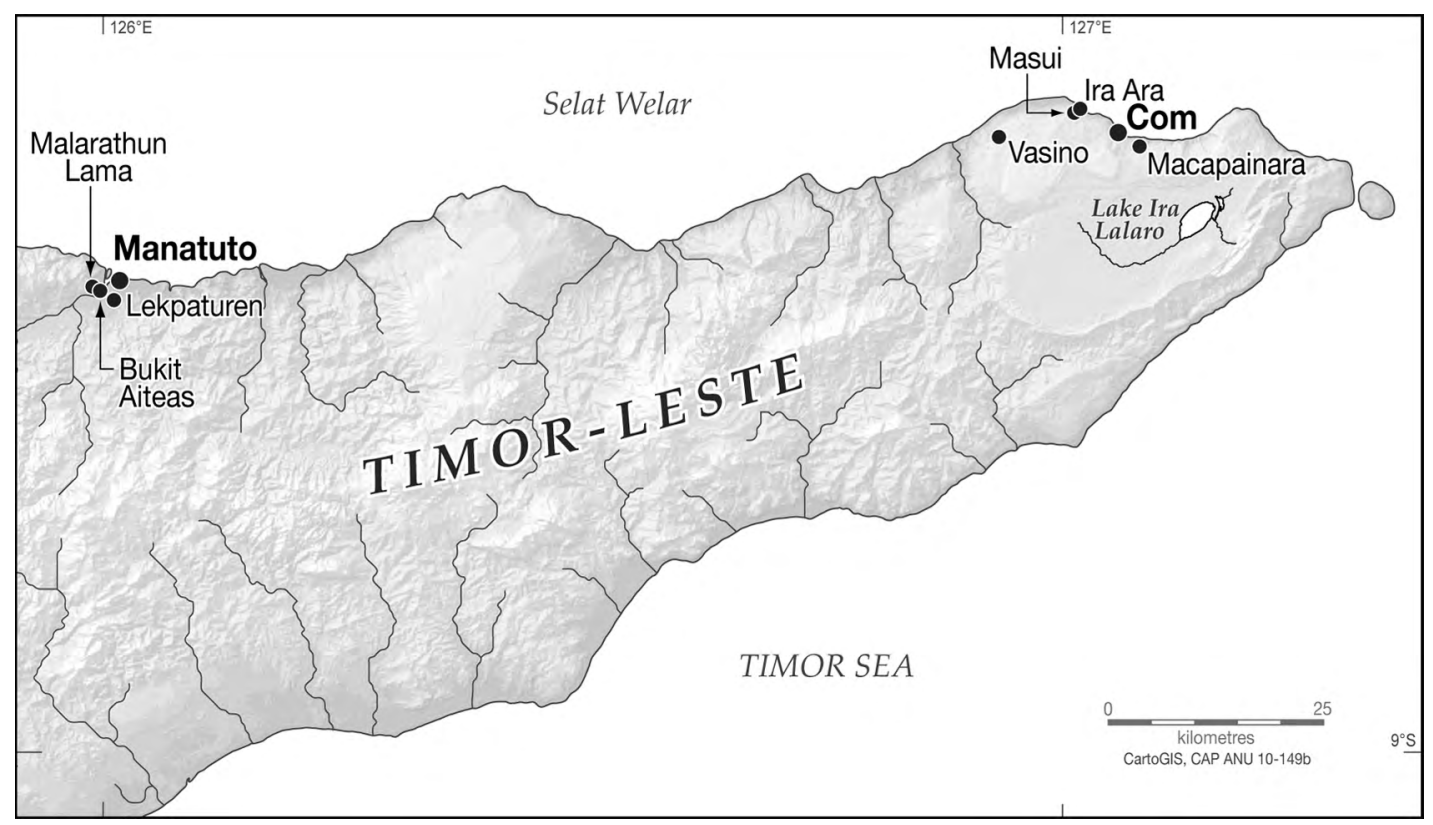

Figure 4.1. Location of Vasino and other fortified sites in Timor-Leste.

Source: CartoGIS ANU. 


\section{Vasino site location and layout}

Vasino was identified during fieldwork in 2008. It was noted at the time that the site was fortified with stone walls similar to those at Macapainara (see Chapter 2, this volume) with large stones on the outside, infilled with smaller rubble. There were also prickly pear plants (Opuntia sp.), an exotic species from the Americas commonly used in Timor to deter intruders (Figure 4.2), and graves laid with so-called batu Makassar, large flat stones, said by the locals to have come from the eponymous Makassar (Figure 4.3; McWilliam et al. 2012). Vasino is a two-level site about $2 \mathrm{~km}$ inland from the northern shore, and $40 \mathrm{~km}$ from the eastern shore of Timor-Leste, within Lautem Province. It is located on a hilltop at an elevation of about $240 \mathrm{~m}$. It is covered with moderately dense vegetation, primarily small trees and shrubs. While well known to local people, this site is not currently used for occupation or agriculture.

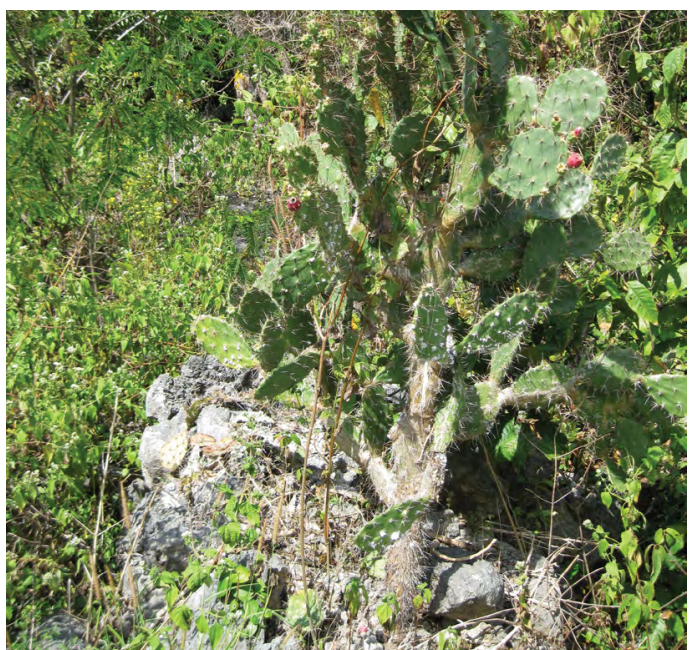

Figure 4.2. Vasino walls and prickly pear.

Source: Photo courtesy of Andrew McWilliam.

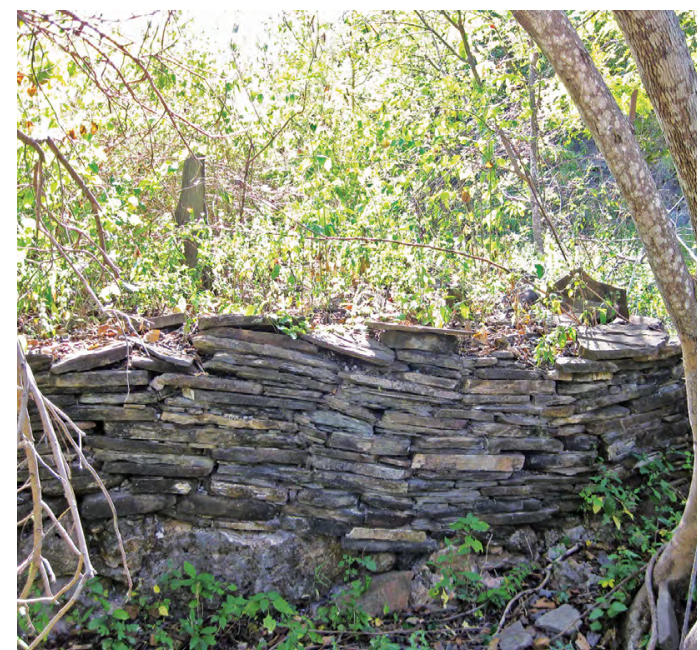

Figure 4.3. Vasino batu Makassar grave.

Source: Photo courtesy of Andrew McWilliam.

The lower level has a nearly flat surface that encompasses an area of $\sim 1950 \mathrm{~m}^{2}$. It is bordered on the west by a high, steep cliff, while stone walls and shorter cliffs line its north and south edges (Figure 4.4). This level contains two stone structures with standing stone markers, which local informants identified as graves, as well as a carved wooden pole (tei or ete uru ha'a) of current sacred significance (Figure 4.5). Its eastern boundary is a 3-5 m high cliff, which also forms the western boundary of the upper level.

The upper level gently slopes from the south down to the north. It covers $-2740 \mathrm{~m}^{2}$, with a $2-4 \mathrm{~m}$ deep natural gully with steep sides along its eastern side. The gully is about $5 \mathrm{~m}$ wide along the northern portion of the upper level and widens considerably as it continues south. To the east of the gully is a rising slope that eventually crests on a hill that overlooks the site. The northern boundary of the upper level is protected by a slope with a series of stone walls, which we have termed the 'Back Entrance'. This area also has a stone wall that projects to the northeast for about $23 \mathrm{~m}$ from the site and then turns at a right angle and continues for another $40 \mathrm{~m}$ to the northwest. The function of this wall is unclear, but it may have a defensive role in protecting the northern hill slope from attack. The upper level has one stone structure identified as a grave, and another, circular structure $15 \mathrm{~m}$ in diameter, which local informants identified as a water buffalo corral $(l o h o)$. The latter seems unlikely since there is no gap in the large stone walls that could have functioned as an entrance. 
Key
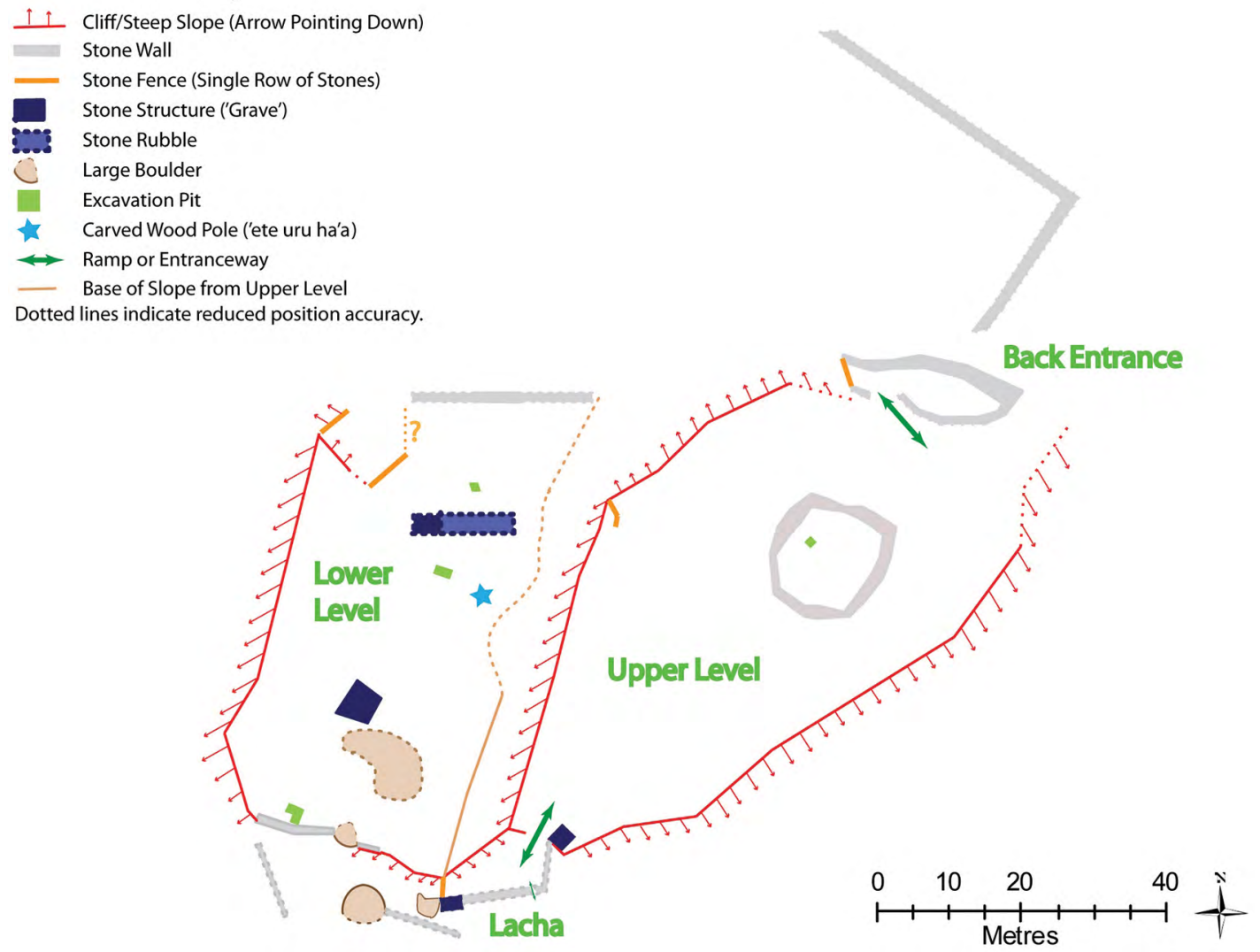

Figure 4.4. Vasino plan of fortifications and features.

Source: Jack Fenner.

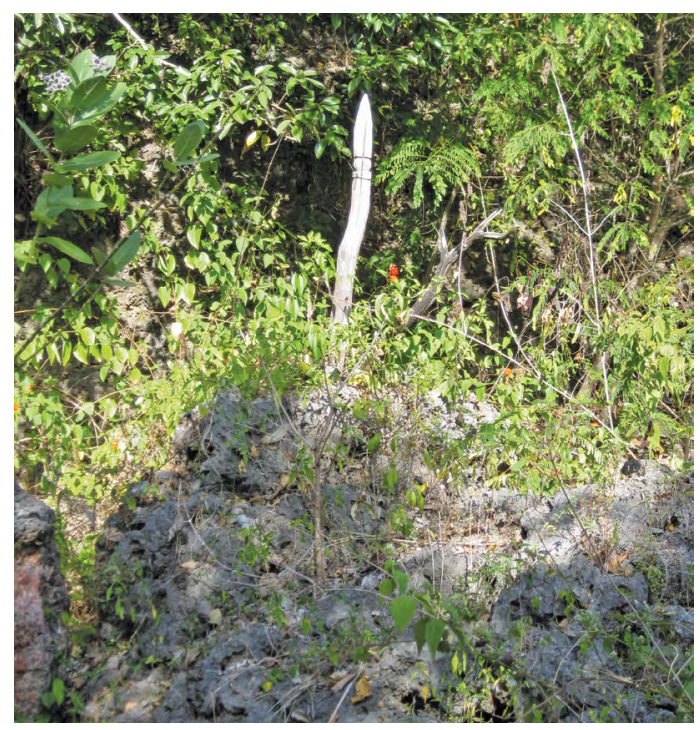

Figure 4.5. Vasino carved wooden pole (tei or ete uru ha'a).

Source: Photo courtesy of Andrew McWilliam.
Vasino's two levels are joined on the south side by a stone wall-lined laca, an internal walled space that is said to be where visitors were greeted. A grave structure is located within the laca at a pinch point between natural stone cliffs about midway along the slope between the two levels. Outside the laca, the ground slopes gently down to the south and east. 


\section{Excavation}

To identify activity areas and determine the chronology of the site, eight $1 \mathrm{~m}$ squares were excavated within the walled enclosure, seven on the lower level and one on the upper level (Figure 4.4). The excavations reached depths of between -50 and $120 \mathrm{~cm}$. Excavation squares were located according to a number of factors: free of trees and other vegetation that could not be cleared by machete; no associated sensitive cultural features (e.g. graves); potential depth of deposit; and, in the case of Squares E, F and G, close to and under a wall feature at the edge of the site.

Squares of $1 \times 1 \mathrm{~m}$ were laid out and excavated in $5-20 \mathrm{~cm}$ spits by trowel, according to finds and conditions within each square. In situ charcoal and shell samples were taken where possible for radiocarbon dating. Bulk sediment samples were taken from each spit for potential palynological and other sediment analyses. The sediment from each spit was weighed so volumes could be calculated for comparisons between spits, and dry sieved through $3 \mathrm{~mm}$ mesh onto the spoil heap.

Rocks were taken from the sediment, weighed separately and discarded onto the spoil heap. Sieve contents were sorted into basic categories onsite (pottery, shell, stone artefacts, bone, charcoal, seeds). Any remaining sediment was weighed and discarded onto the spoil heap. Finds were then taken to the village of Moro, where they were washed and shell was categorised roughly into biological taxa. Cultural material was subsequently analysed in detail according to methods outlined below.

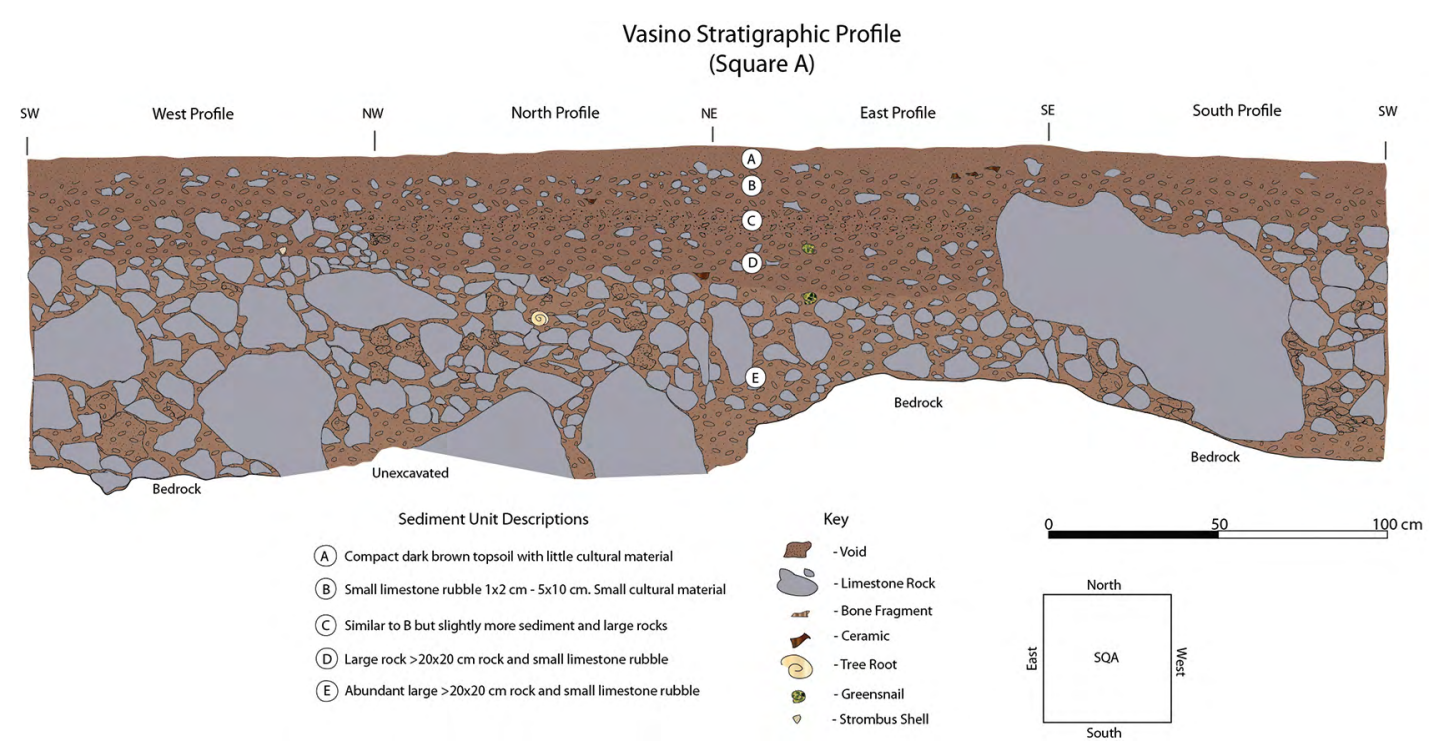

Figure 4.6. Vasino Square A section drawing.

Source: Tim Maloney.

Square A was located near a wall close to the northern end of the site in a locale clear of vegetation that appeared to have a good depth of deposit. The square reached a depth of $94 \mathrm{~cm}$ before bedrock or large rocks were encountered that covered the entire base (Figure 4.6). The deposits were excavated in six spits. In Spit 1, the sediment was very compact but became looser with depth and contained small stones. It contained shell, pottery, bone, stone, seeds and charcoal throughout. Some red slip and painted pottery was present. Both shell and pottery were broken into small pieces, but these became larger and increasingly dense in the middle of the deposit. In Spit 4, an undressed batu Makassar $(12.5 \times 12.5 \mathrm{~cm})$ was located on the northern wall of the deposit; the sediment contained large rocks and there were not many finds. In Spit 5, the sediment was less organic and consisted mostly of small rocks. An extremely large rock, $40-50 \mathrm{~kg}$, was removed from 
the centre of this spit. Most of the sediment in Spit 6 (80 per cent) consisted of small rocks. The cultural material decreased towards the base of the deposit where it was dominated by land snails and there was only one small piece of pottery. The large rocks removed from Spit 4 onwards resulted in large spit depths.

Square $\mathrm{C}$ reached a depth of $54 \mathrm{~cm}$ before bedrock was encountered (Figure 4.7). There were four spits. Finds included shell, pottery, bone, stone, seeds and charcoal. There were few finds in the top spit but by Spit 3, a dense concentration of pottery and bone became apparent. The base of Spit 3 was dominated by large immovable rocks on the northern and southwestern walls. Finds decreased in the last spit, which was dominated by land snails. Large rocks appeared throughout the deposit and their removal resulted in uneven spit depths.

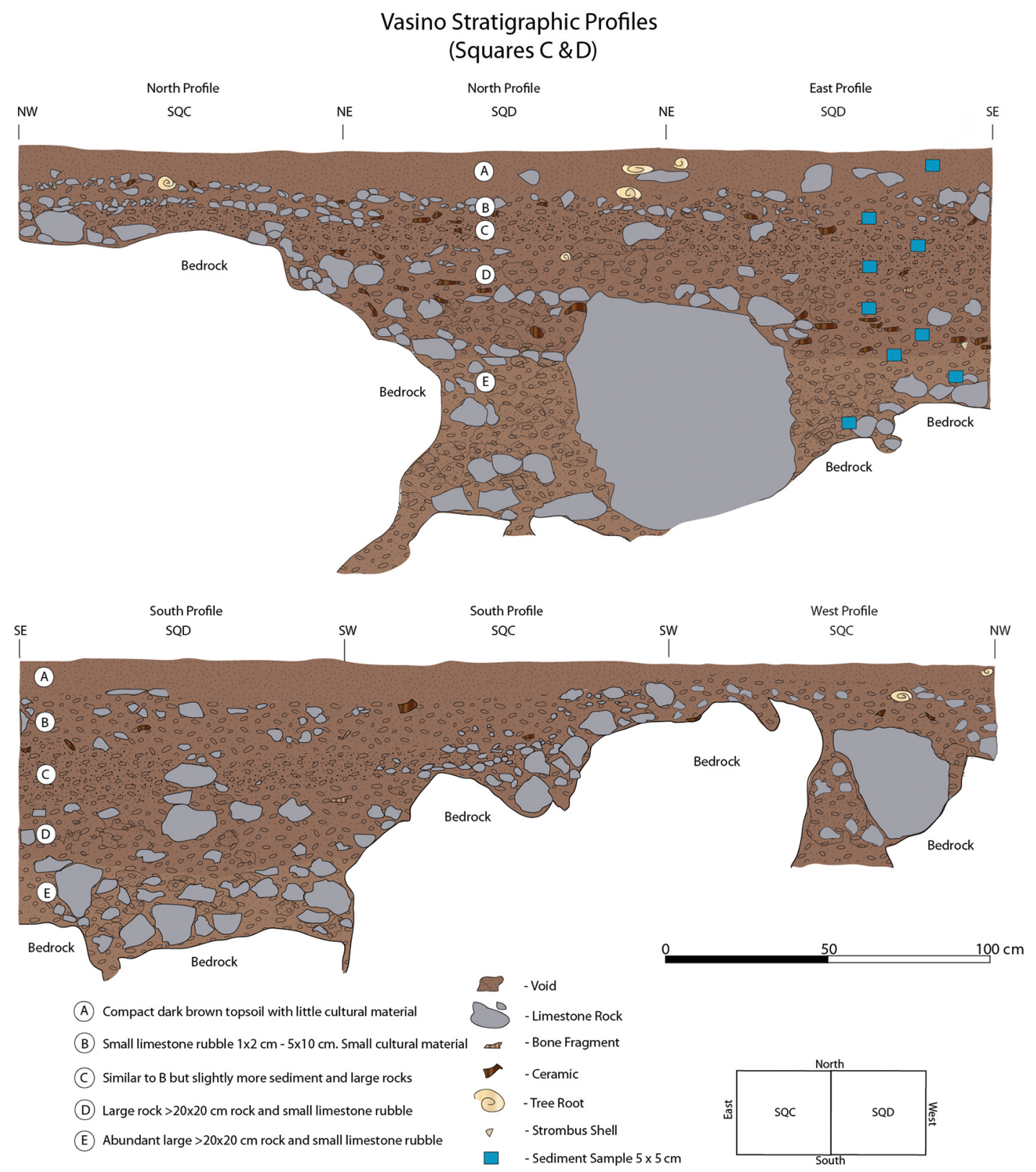

Figure 4.7. Vasino Squares C and D section drawing.

Source: Tim Maloney. 
Square D was an extension of Square $\mathrm{C}$ and was excavated to avoid the large rocks encountered in Square C. It reached a depth of $120 \mathrm{~cm}$, at which point bedrock was reached. It contained 10 spits (Figure 4.7). Finds included shell, pottery, bone, stone, seeds and charcoal. The top layer of deposit consisted of clumping, clayey sand that was dark in colour and contained little cultural material or rock. Spit 2 contained looser sediment with more small and medium rocks. The frequency of both finds and rocks increased with depth, and by Spits 3-5, large amounts of pottery, bone and marine shell were being recovered. There were more small rocks in Spits 5 and 6. There was a hearth with some charcoal in the centre of the northern wall of Spit 6 . The number of small rocks in the sediment increased in Spit 7, while cultural material decreased from then onwards. By Spit 8, the sediment was much rockier though there was still marine shell present. Spit 9 marked the beginning of the land snail horizon. The removal of large rocks in Spit 10 made this a large spit. Square D was disturbed by two large potential rodent holes in the northeast corner in Spit 3, and in Spit 10 another hole appeared on the northwest wall of the trench.

Square $\mathrm{E}$ was located on the southern end of the site near to a fortress wall. It was $51 \mathrm{~cm}$ deep curtailed by a base of large rocks. There were six spits (Figure 4.8). Finds included shell, pottery, bone, stone, seeds, charcoal and a perforated disc (discussed below). Spit 1 consisted of hard compacted soil with no rocks, and there were relatively few finds and no charcoal. However, the soil of Spits 2-4 was dark and humic, and there was a dense concentration of cultural material, especially pottery and bone. Spit 3 contained more rocks, which decreased by Spit 4. In Spit 5, large immovable rocks were apparent in the corners and the centre of the trench, with much less pottery; here the land snail horizon began. Spit 6 contained mostly land snail, with few other finds.

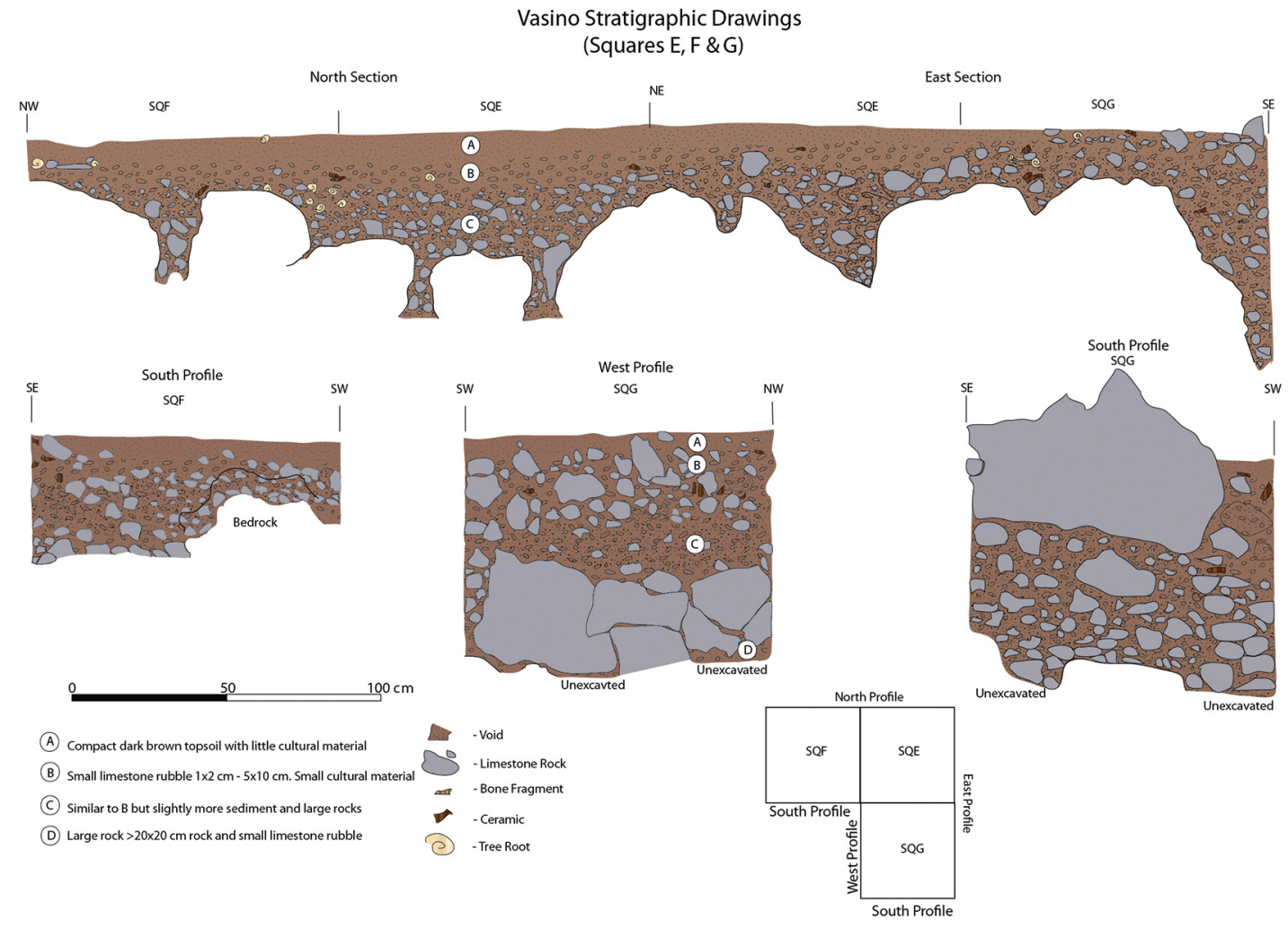

Figure 4.8. Vasino Squares $E$, $F$ and $G$ section drawing.

Source: Tim Maloney. 
Square $\mathrm{F}$ was adjacent to the east wall of Square E. It was $38 \mathrm{~cm}$ deep and contained four spits (Figure 4.8). The base was rocky. Finds included shell, pottery, bone, stone, seeds and charcoal. The first spit was a hard compacted layer, disturbed by tree roots. The second spit contained many rootlets, a large rock began to appear on the western wall, much pottery was found and there was a pig's tusk and a perforated disc (discussed below). Spit 3 also contained large amounts of pottery and bone, with an increased amount of marine shell and the deposits becoming increasingly rocky on the western wall. The fourth spit was very rocky, with large amounts of pottery still apparent and an increase in the number of stone artefacts. Land snail increased towards the base where there were fewer finds.

Square $\mathrm{G}$ was adjacent to the south wall of Square E, immediately next to the fortress wall (Figure 4.8). It was $68 \mathrm{~cm}$ deep and contained seven spits. The base was covered in large rocks. Finds included shell, pottery, bone, stone, seeds and charcoal. The top spit contained many finds, including large amounts of pottery. The large number of finds continued until Spit 4, though it was increasingly rocky. In Spit 5, the number of finds decreased and large rocks dominated the western and southern walls. By Spit 6, land snail was dominant, though there was still some pottery. Spits 6 and 7 were larger and contained higher quantities of rock and land snail.

Square $\mathrm{H}$ was located in the upper level of Vasino (Figure 4.4). It was situated on a flat earth base in the side of a rocky hill. It was $38 \mathrm{~cm}$ deep and contained four spits. The base was reached at bedrock. Finds included shell, pottery, bone, stone, seeds and charcoal. Spits 1 and 2 consisted of hard compacted soil with some rocks and contained many stone artefacts, some pottery and shell. By Spit 3, bedrock dominated the western half of the square. A large hearth appeared at the top of Spit 4 and came directly down onto bedrock at the base of the spit (Figure 4.9).

Although there were differences between the squares, the general impression we gained from the excavations was that a top layer with few finds and much land snail was followed by a dense cultural layer containing shell, pottery, bone, stone, seeds and charcoal, followed by a third layer coming down onto bedrock that was again dominated by land snail.

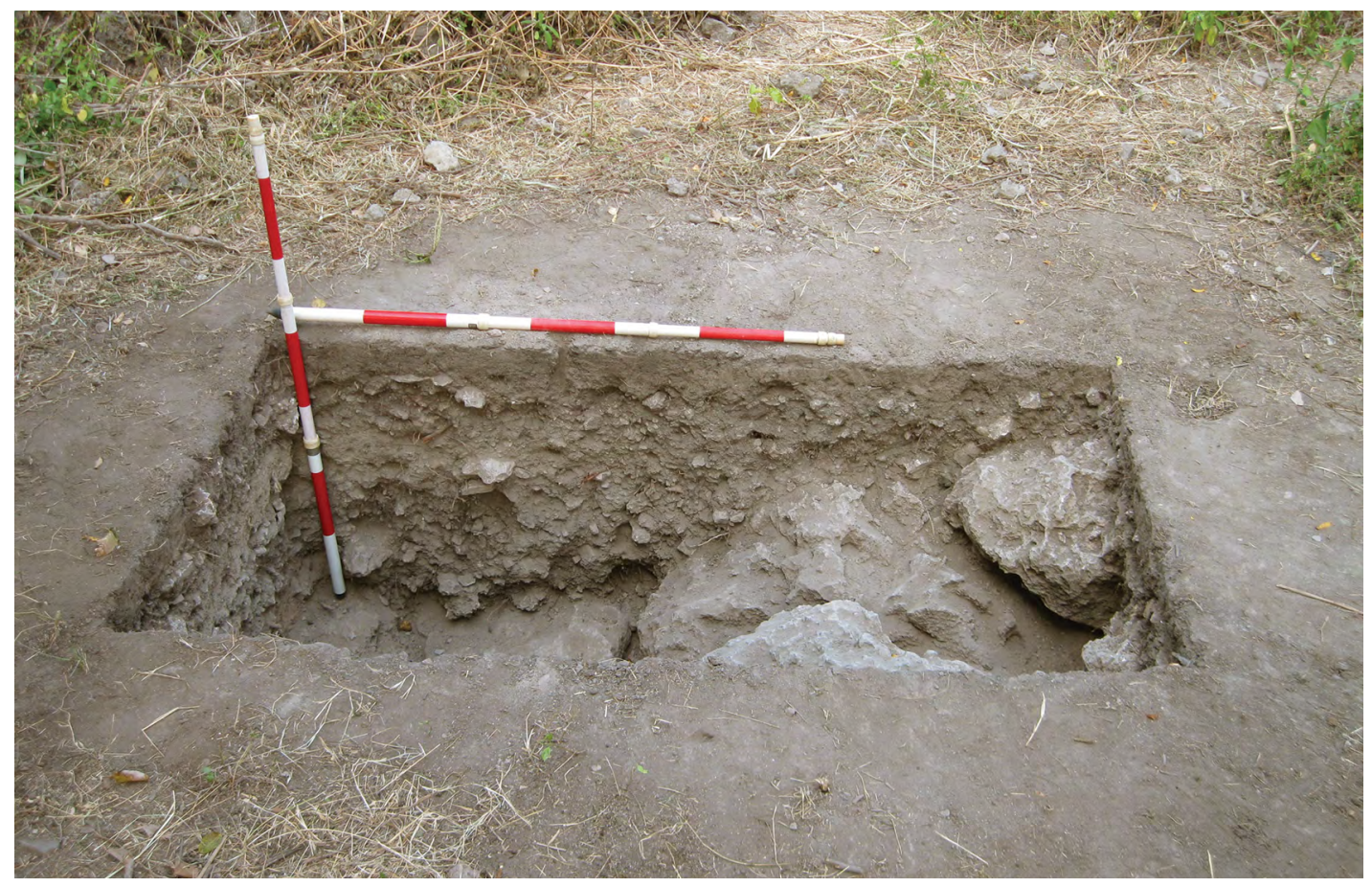

Figure 4.9. Vasino Square $\mathrm{H}$ : photo of section.

Source: Photo courtesy of Sally Brockwell. 


\section{Radiocarbon and chronology}

Twenty-six AMS (accelerator mass spectrometry) radiocarbon dates have been obtained for Vasino (Table 4.1, Figure 4.10). Samples for dating were not point-positioned during excavation, so all samples were derived from sieve residue. Six dates obtained from Turbo bruneus marine mollusc shell appear to be unreliable: their $\delta^{13} \mathrm{C}$ values vary widely, duplicate measurements of the same shell (ANU19913 and ANU19914) produced very different radiocarbon dates, and most dates are much younger than charcoal dates from the same spits. The latter problem could be partially explained by a local marine radiocarbon offset $(\Delta \mathrm{R})$, but it would require a local offset of about 1000 years for the earliest dates to correspond with charcoal-based dates from the same spits. Given the nature and severity of these problems, shell radiocarbon data are not included in any of the Vasino date estimates.

Table 4.1. Vasino radiocarbon dates.

\begin{tabular}{|c|c|c|c|c|c|c|}
\hline Square & Spit & Material & Lab ID & $\delta^{13} \mathrm{C}^{1}$ & Radiocarbon date (RCYBP) & Calibrated range (year AD; 95\% range) ${ }^{2}$ \\
\hline A & 2 & Charcoal & ANU12626 & -27.3 & $510 \pm 20$ & 1420 to 1452 \\
\hline A & 3 & Charcoal & ANU12627 & -27.4 & $590 \pm 20$ & 1327 to 1337,1391 to 1428 \\
\hline A & 3 & Shell & ANU19909 & 7.0 & $2190 \pm 35$ & 79 to 257 \\
\hline A & 5 & Charcoal & ANU12710 & -21.1 & $1180 \pm 30$ & 886 to 991 \\
\hline A & 5 & Shell & ANU19910 & 1.3 & $2205 \pm 35$ & 63 to 242 \\
\hline A & 6 & Charcoal & ANU12629 & -25.0 & $670 \pm 30$ & 1299 to 1395 \\
\hline C & 2 & Charcoal & ANU12635 & -26.5 & $410 \pm 30$ & 1454 to 1511,1573 to 1621 \\
\hline C & 3 & Charcoal & ANU12636 & -25.4 & $430 \pm 20$ & 1450 to 1502,1591 to 1614 \\
\hline C & 4 & Charcoal & ANU12637 & -26.8 & $420 \pm 20$ & 1452 to 1506,1586 to 1618 \\
\hline D & 1 & Charcoal & ANU12638 & -28.9 & $130 \pm 20$ & 1692 to 1727,1806 to 1870,1876 to 1920 \\
\hline D & 2 & Charcoal & ANU12709 & -14.4 & $960 \pm 30$ & 1037 to 1186 \\
\hline D & 2 & Shell & ANU19911 & 2.7 & $850 \pm 35$ & 1420 to 1524 \\
\hline D & 4 & Shell & ANU19912 & 8.0 & $1275 \pm 35$ & 1048 to 1218 \\
\hline D & 7 & Charcoal & ANU12639 & -28.8 & $200 \pm 20$ & 1662 to 1701,1721 to 1809 \\
\hline D & 7 & Shell & ANU19913 & 8.4 & $2345 \pm 35$ & $101 \mathrm{BC}$ to 86 \\
\hline D & 7 & Shell & ANU19914 & -2.8 & $1115 \pm 35$ & 1213 to 1336 \\
\hline$D$ & 10 & Charcoal & ANU12630 & -28.5 & $490 \pm 20$ & 1426 to 1458 \\
\hline$E$ & 2 & Charcoal & ANU12631 & -27.2 & Modern & $\sim 1974$ \\
\hline$E$ & 6 & Charcoal & ANU12631 & -27.2 & $380 \pm 20$ & 1477 to 1627 \\
\hline $\mathrm{F}$ & 2 & Charcoal & ANU12633 & -28.6 & $90 \pm 20$ & 1701 to 1722,1810 to 1837,1880 to 1921 \\
\hline $\mathrm{F}$ & 4 & Charcoal & ANU12619 & -24.8 & $400 \pm 20$ & 1457 to 1512,1547 to 1566,1568 to 1622 \\
\hline $\mathrm{G}$ & 1 & Charcoal & ANU12620 & -26.7 & Modern & $\sim 1983$ \\
\hline G & 7 & $\begin{array}{l}\text { Celtis sp. } \\
\text { nut case }\end{array}$ & ANU12625 & -10.5 & $360 \pm 30$ & 1484 to 1638 \\
\hline G & 7 & Charcoal & ANU12621 & -26.9 & $210 \pm 20$ & 1658 to 1693,1727 to 1805 \\
\hline $\mathrm{H}$ & 1 & Charcoal & ANU12623 & -25.6 & $320 \pm 20$ & 1508 to 1583,1619 to 1649 \\
\hline $\mathrm{H}$ & 4 & Charcoal & ANU12624 & -25.0 & $170 \pm 20$ & $\begin{array}{l}1672 \text { to } 1743,1798 \text { to } 1819,1825 \text { to } \\
1893,1922 \text { to } 1933\end{array}$ \\
\hline
\end{tabular}

Notes:

1 ANU Radiocarbon Lab $\delta^{13} \mathrm{C}$ values are not directly comparable with $\delta^{13} \mathrm{C}$ values obtained using IRMS (isotope-ratio mass spectrometry) for stable isotope analysis.

2 Calibrated using BCal (Buck et al. 1999) and the SHCal04 calibration curve (McCormac et al. 2004).

Source: Jack Fenner. 


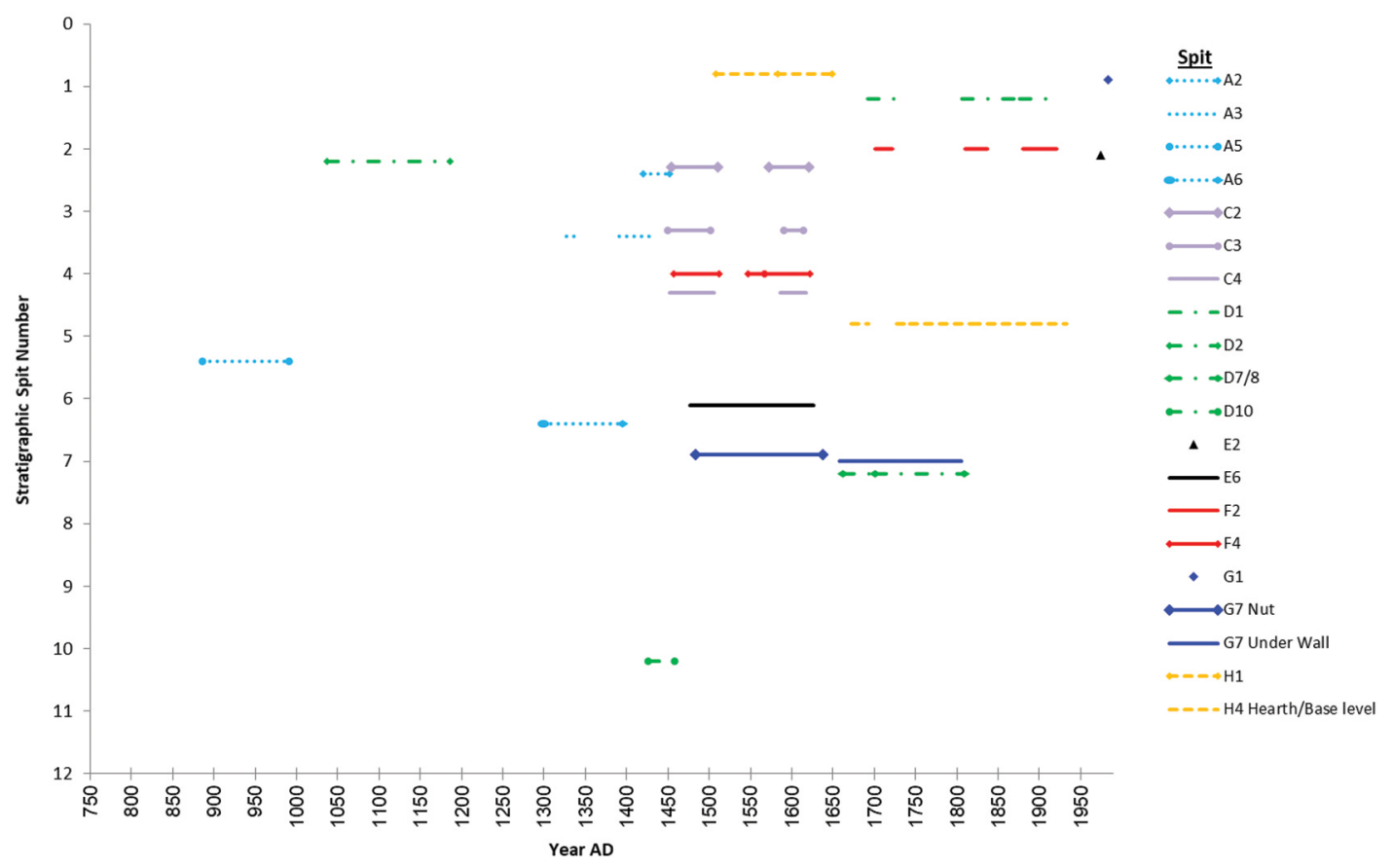

Figure 4.10. Vasino radiocarbon dates (excludes shell-based dates).

Source: Jack Fenner.

As discussed in the Excavation section, there was no visible stratigraphy at Vasino so we cannot rely on this indicator when assessing square disturbance and, in the absence of micromorphology or other forms of sediment analysis, we must use date inversions. The dates for Square D in particular indicate a large inversion in Spit 2 or 7 (Table 4.1), so Square D dates are excluded from site chronology estimations. Also, Square A Spit 5 shows a major inversion with a date that is substantially earlier than those from Spit 3 above it or Spit 6 below it; in fact, the Spit 5 date is earlier than any other date from the site. The Spit 6 date is in line with what would be expected based on the dates from Spit 2, so the problem may be related solely to the Spit 5 date. We nevertheless took the conservative approach and excluded the dates from both Spits 5 and 6 from Vasino date estimates.

The only other date inversion is between Spits 1 and 4 of Square H. This square contains lots of burnt material, which may be derived from a hearth that spanned multiple spits. Nevertheless, the Square $\mathrm{H}$ dates are recent enough that they are unlikely to affect overall site dating (although they are the only dates available for the upper level of the site). Except for Square D, there were no burrows or other disturbances visible during excavation, so all other dates are considered valid. Excluding the six shell dates, four dates from Square D and two dates from Square A, a total of 14 reliable dates remain. Two of these, however, are from near-surface samples that postdate AD 1950 and are therefore excluded.

Bayesian analysis of radiocarbon dates can contribute to determining the start of occupation at Vasino by providing a quantitative estimation of the probability that site occupation (as identified by radiocarbon dates) was later than a specific date. Essentially it combines the probability distributions of all calibrated radiocarbon dates and then uses this distribution to estimate the site occupation probabilities. The method is discussed elsewhere (Fenner and Bulbeck 2013); in this analysis all Bayesian estimates are performed using the BCal online Bayesian radiocarbon analysis tool (Buck et al. 1999). 


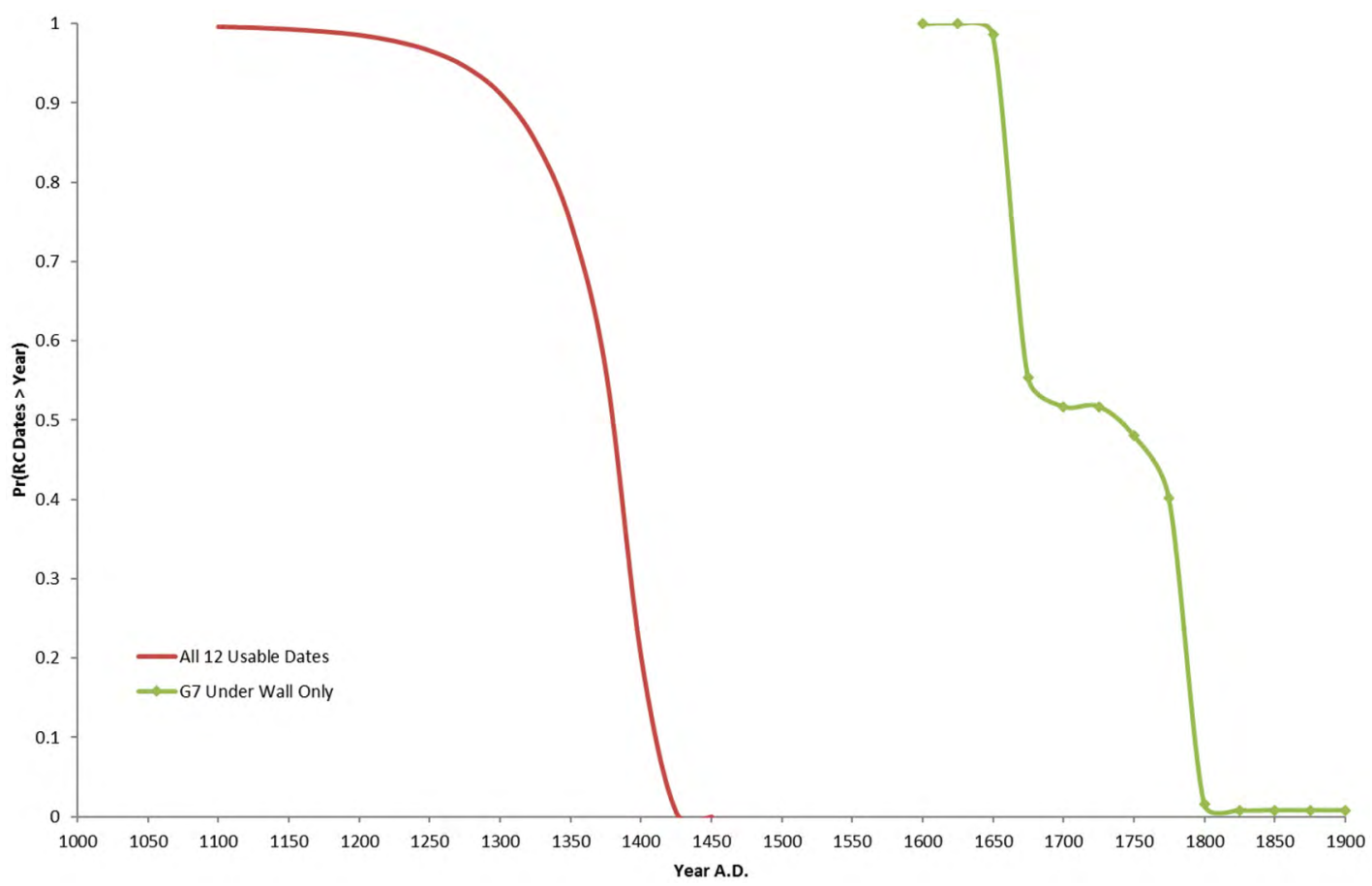

Figure 4.11. Vasino Bayesian model.

Source: Jack Fenner.

Using the Bayesian approach results in an estimate of a 91 per cent probability that Vasino dates to later than $\mathrm{AD} 1300$, a 75 per cent probability that it is later than $\mathrm{AD} 1350$, a 50 per cent probability that it is later than AD 1375, a 20 per cent probability that it is later than $A D 1400$, and a 0 per cent probability that it is later than AD 1425 (Figure 4.11). The initial site occupation thus most likely falls in the second half of the fourteenth century.

As the basal spits of the excavated squares all came down onto bedrock with decreasing amounts of cultural material and increasing quantities of land snail, it was concluded that the basal dates mark initial site occupation. However, it is important to note that this analysis is considered likely to date the start of occupation at Vasino, rather than start of fortifications. There is only one radiocarbon date directly related to the start of fortifications: ANU12621 is from charcoal obtained from under the site perimeter wall adjacent to Square G at Spit 7. This date is more than 250 years later than the initial site occupation date (Figure 4.11) and would, if used alone, indicate that fortifications started much later than previously suggested.

\section{Post-excavation methods and results}

\section{Earthenware pottery}

Just over $50 \mathrm{~kg}$ of earthenware pottery was recovered (Bulbeck 2011). Owing to time constraints, most of the plain pottery was recorded just for its weight, and only rim and decorated sherds were all recorded in terms of their sherd counts and detailed observations (see below). Base sherds were also recorded when they could be related to rim sherds, as well as one identified handle to a cover, but no spouts were observed. The textbook source used for general observations was Shepard (1974), and the source used for identifying firing and other manufacturing methods was Rye (1981). Shepard's textbook outlines a geometric system for classifying any vessel form, including allowance for contour complexities such as pedestals, which can then be applied to the 
pottery assemblage under analysis. Also owing to time constraints, illustrations and photographs of the Vasino decorated sherds were not prepared, but they are similar to their Macapainara counterparts (see Chapter 2, this volume).

Where undertaken, detailed observations included rim shape and (where possible to estimate) vessel form and approximate rim diameter, any decorations, signs of surface finish and manufacturing technique, and internal and external Munsell colours (for further explanation, see Chapter 2, this volume). This was done for all of the pottery from Spits 4 and 5 of Square A and Spits 2 to 5 of Square G, in the former case because the fabric of the pottery appeared generally different from the other spits, and in the latter case because the generally large size of the sherds made it feasible to assign a large proportion of the sherds to the original vessels from which they had come. In these latter cases, the assignment of vessel form is more secure than when it is based just on rim form, but even here the vessel form identifications are based primarily on rim characteristics. The general description of the Vasino pottery in the following paragraphs is based on the $11.96 \mathrm{~kg}$ (24 per cent of the assemblage) recorded in detail.

The majority of vessels were apparently formed using the paddle-and-anvil technique and finished on a slow wheel. Approximately 6 per cent of the pottery is decorated (Table 4.2), usually in the form of paddle-applied impressions, mainly faint vertical lines $(2.3 \mathrm{~kg})$ but also faint horizontal lines $(105 \mathrm{~g})$ and sharp rectangular impressions $(46 \mathrm{~g})$. A rare form of decoration involved the use of a reddish clay-based paint to create dots, lines and other curvilinear shapes, recorded on $88 \mathrm{~g}$ of the total assemblage. Other rare forms of decoration included notched corrugations $(125 \mathrm{~g})$, pinched and appliqué nubbins $(65 \mathrm{~g})$, incised, impressed and gouged lines (102 g together), wheel-thrown horizontal lines $(62 \mathrm{~g})$, and single examples of a punched hole, cord-marking and an appliqué medallion.

Table 4.2. Vasino earthenware pottery weights by square $(g)$.

\begin{tabular}{|c|c|c|c|}
\hline Square & Decorated sherd weight & Total sherd weight & Percentage decoratec \\
\hline A & 46.6 & $1,444.4$ & 3.2 \\
\hline C & 440.5 & $7,310.5$ & 6.0 \\
\hline D & $1,500.6$ & $20,616.2$ & 7.3 \\
\hline$E$ & 115.6 & $6,793.9$ & 1.7 \\
\hline $\mathrm{F}$ & 96.5 & $5,573.5$ & 1.7 \\
\hline G & 707.2 & $7,458.6$ & 9.5 \\
\hline $\mathrm{H}$ & 13.3 & $1,113.5$ & 1.2 \\
\hline Total & 2,920.3 (88.3 g painted) & $50,310.6$ & 5.8 \\
\hline
\end{tabular}

Source: David Bulbeck.

Based on the tightly knit and low-porous nature of the fabric, most of the assemblage appears high-fired by earthenware standards, occasionally bordering on stoneware (cf. Rye 1981). The temper of the Vasino sherds consists of foraminiferal calcareous grains, sometimes combined with a dominant element of massive terrigenous grains, or limeclast calcareous grains (occasionally mixed with foraminiferal calcareous grains). These temper additions led to the white speckling visible macroscopically on most of the Vasino (as well as Macapainara) sherds (Dickinson 2011). The external surface was usually coloured brown $(6.8 \mathrm{~kg})$, especially reddish brown $(4.0 \mathrm{~kg})$, and otherwise grey $(4.7 \mathrm{~kg})$, often pinkish or reddish grey $(2.1 \mathrm{~kg})$. Rare surface colours included dark red $(325 \mathrm{~g})$, usually associated with a distinctive slipped and burnished variety of ware, as well as black (122 g), recorded on some highly reduced sherds, pink $(6 \mathrm{~g})$, white $(6 \mathrm{~g})$ and reddish yellow $(5 \mathrm{~g})$. External surface finishing included smoothing $(5.7 \mathrm{~kg})$ and polishing $(20 \mathrm{~g})$, as well as self-slipping $(256 \mathrm{~g})$ and the application of a red slip (359 g), black slip (15 g) or white slip $(11 \mathrm{~g})$. Even the $5.6 \mathrm{~kg}$ of sherds that did not clearly have these surface finishing effects showed some attention to finish, in the form of external wiping marks on around 40 per cent of them. 
Vessel form could be determined for 287 vessels (Table 4.3). Most or all of these vessels would be distinct vessels (comparable to the 'estimated vessel equivalents' of Orton and Tyers 1991) even if the real number of vessels represented by the assemblage may be much greater than 287 . The great majority were classified as jars (91 per cent), comparable to Shepard's (1974) Fig. 21(h) structural class, based on possessing a neck and everted rim. Most of these appear to be mediumsized jars ( 83 per cent of vessels) with a rim diameter between 11 and $18 \mathrm{~cm}$ where it could be estimated (vessel height estimates unfortunately unavailable). Most of the medium-sized jars have thin rims and rounded lips, but even these show considerable variability. Other jars have thick short rims, while a very unusual variant observed on two sherds from Square D Spit 6 involves lobed rims resulting from the great variability of rim thickness and shape observable on a single sherd. A small number of jars have squarish rims (Figure 4.12). Only a small number of jars appeared to be large (7 per cent of vessels) with a rim diameter of $20 \mathrm{~cm}$ or more, or small jars ( 1 per cent of vessels) with a rim diameter up to $10 \mathrm{~cm}$. One use of the medium-sized jars may have been as cooking pots, based on their similarity to the periuk cooking pots so commonly recorded for Indonesian pottery assemblages (Santoso 1995), although only one Vasino sherd was recorded to have carbonised traces (on an interior surface). The large jars were presumably used as storage vessels. Very few of the jars ( 2 per cent) appear to have been covered with lids, and only one sherd, which appears to be a cover handle, was identified.

Table 4.3. Vasino earthenware vessel forms.

\begin{tabular}{|c|c|c|c|c|}
\hline Vessel form & $\begin{array}{l}\text { Number } \\
\text { recorded }\end{array}$ & $\begin{array}{l}\text { Average rim } \\
\text { diameter }(\mathrm{cm})\end{array}$ & Rim diameter range $(\mathrm{cm})$ & Distribution in site \\
\hline Cup & 4 & 10.5 & $8-13$ & $\mathrm{C} 2, \mathrm{E} 2, \mathrm{E} 4, \mathrm{G} 6$ \\
\hline Plate & 11 & 14.0 & $13-19$ & $\mathrm{D} 3, \mathrm{D} 4, \mathrm{E} 3, \mathrm{~F} 2, \mathrm{~F} 3, \mathrm{G1}, \mathrm{G} 4, \mathrm{H1}, \mathrm{H} 3$ \\
\hline Bowl & 7 & 23.3 & $17-30$ & $\mathrm{C} 1, \mathrm{D} 3, \mathrm{D} 4, \mathrm{D} 5, \mathrm{D} 6, \mathrm{E} 4, \mathrm{~F} 2, \mathrm{~F} 3$ \\
\hline Constricted vessel & 4 & Not recordable & Not recordable & $\mathrm{C} 2, \mathrm{E} 3, \mathrm{G} 4$ \\
\hline Small jar & 4 & 10 & 10 & $\mathrm{C} 4, \mathrm{D} 6, \mathrm{G} 2, \mathrm{G} 3$ \\
\hline Medium-sized jar & 235 & 14.9 & $11-18$ & $\begin{array}{l}\mathrm{C} 3, \mathrm{C} 4, \mathrm{D} 2, \mathrm{D} 3, \mathrm{D} 4, \mathrm{D} 5, \mathrm{D} 6, \mathrm{D} 7, \mathrm{D} 8, \\
\mathrm{D} 9, \mathrm{E} 2, \mathrm{E} 3, \mathrm{E} 4, \mathrm{E} 5, \mathrm{~F} 1, \mathrm{~F} 2, \mathrm{~F} 3, \mathrm{~F} 4, \mathrm{G} 1, \\
\mathrm{G} 2, \mathrm{G} 3, \mathrm{G} 4, \mathrm{G} 5, \mathrm{G} 6, \mathrm{H} 1, \mathrm{H} 2\end{array}$ \\
\hline Medium-sized covered jar & 5 & 12.8 & $11-15$ & $\mathrm{D} 2, \mathrm{D} 4, \mathrm{D} 5, \mathrm{D} 6$ \\
\hline Large jar & 15 & 22.0 & $20-24$ & $\begin{array}{l}\text { A3, C1, C2, C3, C4, D2, D3, D5, D6, } \\
\text { G3, G4 }\end{array}$ \\
\hline Large covered jar & 1 & 23 & 23 & D6 \\
\hline Stove & 1 & Not recordable & Not recordable & D6 \\
\hline
\end{tabular}

Source: David Bulbeck.

Apparent serving vessels were classified as cups (1 per cent), small vessels similar in shape to Shepard's (1974) Fig. 20(1) structural class, plates (4 per cent), comparable to Shepard's Figs 20(a) and 21(a) structural classes, and bowls (2 per cent), comparable to Shepard's Fig. 20(m) structural class. The plates, with a rim form suggestive of a shallow unrestricted vessel, may include some covers to jars, but even so the great majority of jars would have lacked covers. There were few bowls but most of these were a distinctive type of vessel with a burnished red-slipped surface and neatly finished foot (Figure 4.13). The only other identifiable vessel type with a similar surface treatment was the collection's single large covered jar, from Square D Spit 6 (Figure 4.13). The red burnished sherd selected as an example of these fine wares for petrological analysis was identified as 'Telepunu' temper, distinguished by limeclast calcareous grains (Dickinson 2011). Finally, three vessels had rims suggestive of a constricted vessel form, and one sherd apparently from a stove, based on the lack of curvature along the rim ledge, was recorded. 


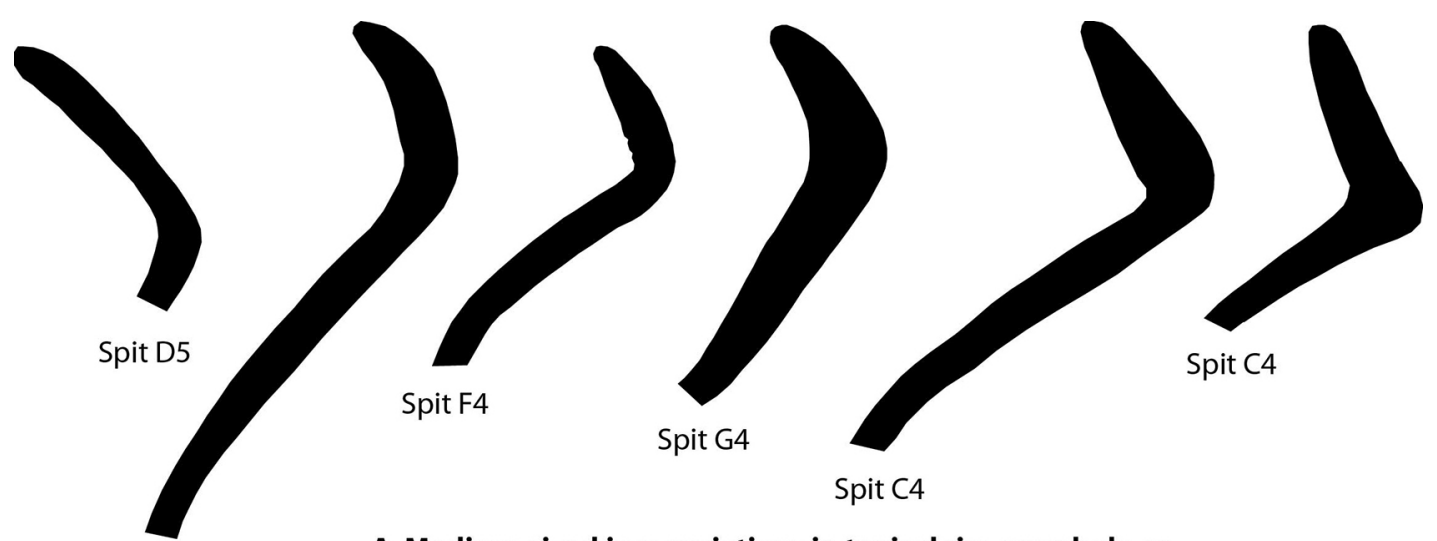

Spit G4

A. Medium-sized jars, variations in typical rim morphology

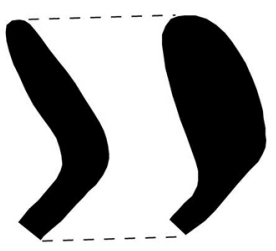

Spit D4

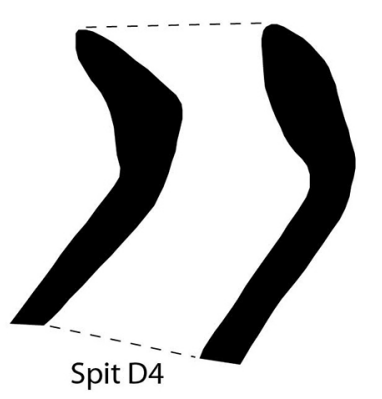

B. Medium-sized jars with lobed rims

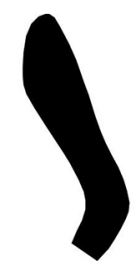

Spit C4

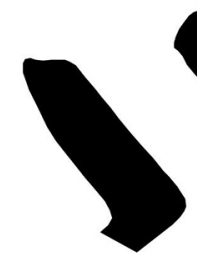

Spit G1

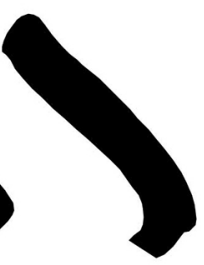

Spit H1

D. Small jar

E. Square-rimmed jars

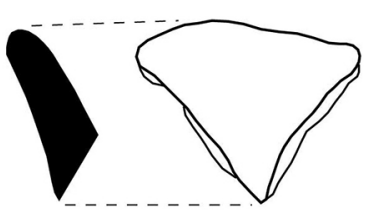

Spit E2

H. Cup

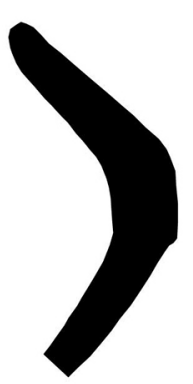

Spit G4

F. Jar with bossed neck

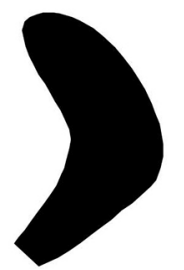

Spit $\mathrm{H} 2$

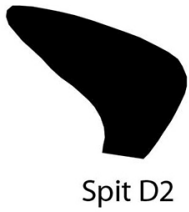

C. Thick-rimmed jars

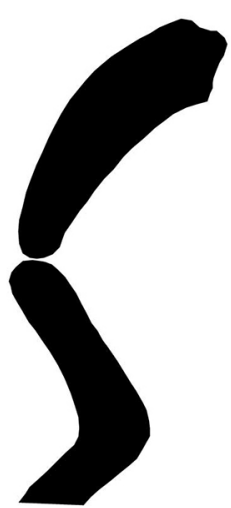

Spit D2

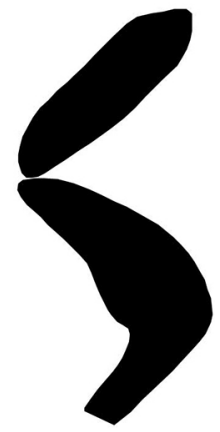

Spit D4

G. Covered medium-sized jars
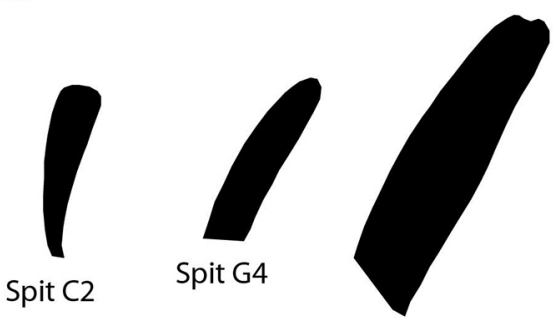

Spit E3

J. Constricted vessels: cup(?) and two jars

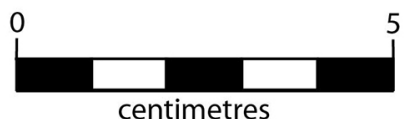

Spit F3

I. Bowl

Figure 4.12. Vasino earthenware pottery rims.

Source: David Bulbeck. 


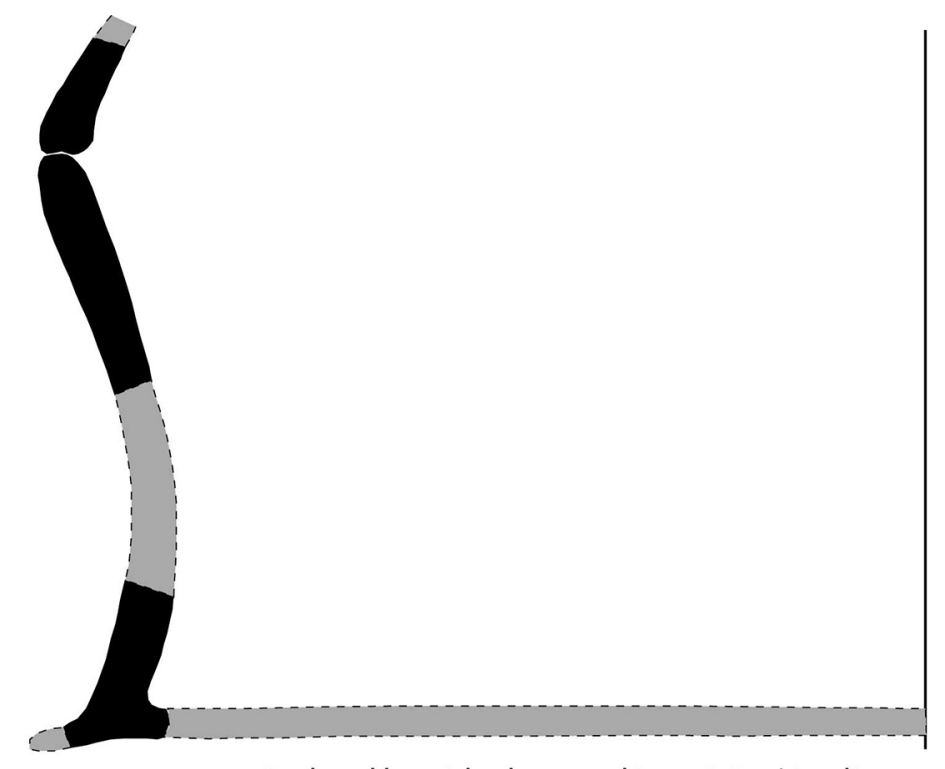

Dark-red burnished, covered jar, spit D6 (rim diameter $23 \mathrm{~cm}$ )

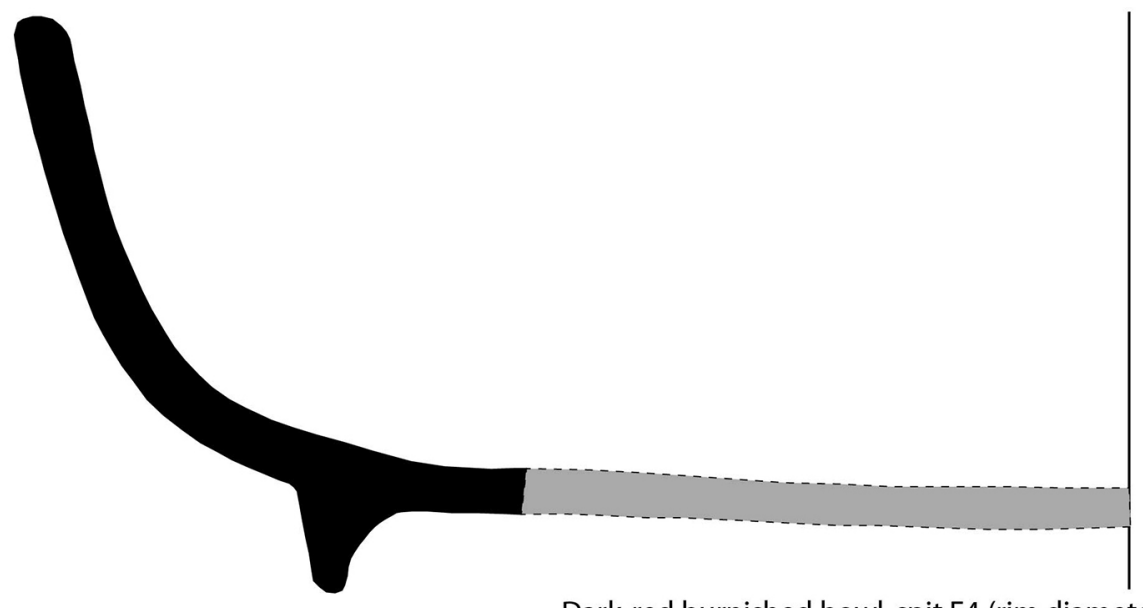

Dark-red burnished bowl, spit E4 (rim diameter $30 \mathrm{~cm}$ )

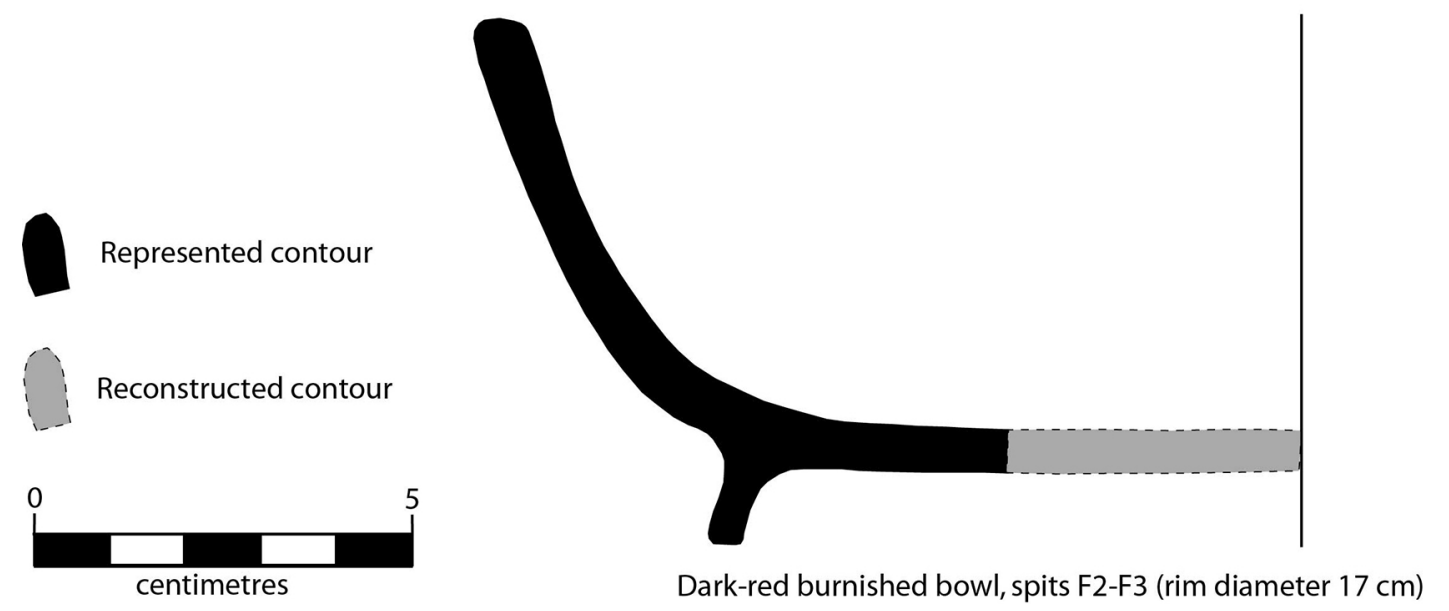

Figure 4.13. Vasino earthenware reconstructible contours.

Source: David Bulbeck. 
The dark red burnished vessels, including the large covered jar and footed bowls, appear to have been manufactured on a fast wheel as indicated by regular, closely spaced wheel-throwing lines. Similar evidence of fast wheel manufacture was recorded on four sherds from mediumsized jars. The most commonly recorded manufacturing techniques were the use of a slow wheel (120 vessels) and the paddle-and-anvil technique (213 vessels), sometimes on the same vessel. Where vessel form could be determined, it was most frequently a medium-sized jar, as expected given the predominance of this vessel form in the collection. Evidence of coil-building was not observed and evidence for hand modelling as the only forming technique was recorded for just a cup, a plate, the stove and eight of the medium-sized jars. The typical production procedure for the Vasino vessels therefore probably involved shaping the jar with a paddle applied externally (often leaving vertical impressions) and an anvil held inside the wall, and the neck and rim finished on a slow wheel.

No wasters were recorded to indicate pottery manufacture at Vasino itself. Blistered surfaces suggestive of overfiring were recorded on only $88 \mathrm{~g}$ of the nearly $12 \mathrm{~kg}$ of Vasino sherds recorded in detail. The sherds appeared to be fully oxidised for $4.2 \mathrm{~kg}$ of the recorded total, although surface clouds and smudges from firing were recorded on a further $3.9 \mathrm{~kg}$ of the assemblage, and evidence of internally reduced walls included dark cores on a further $947 \mathrm{~g}$ of the assemblage. Internally or externally reduced surfaces, occurring together or in combination with a reduced internal wall, were recorded for $2.9 \mathrm{~kg}$ of the assemblage, including $327 \mathrm{~g}$ where the sherd was reduced entirely. The above observations in most cases would reflect firing conditions for the vessels during their manufacture, although in some cases post-manufacture exposure to heat (such as an open fire) may have left surface clouds or an apparently reduced surface.

\section{Imported tradewares}

Tradewares are high-fired ceramics, often with patterns, that have been imported from Mainland Asia, starting around the tenth century, usually of Chinese origin (Habu et al. 2017: 154). They are of much finer quality than earthenware. Only three tradeware sherds were recovered from Vasino. These were examined to identify possible manufacture locations according to categories presented in the literature on trade ceramics in the region (Bulbeck 2012; Frasché 1976; Guy 1986; Harrisson 1995; Li 2010).

One sherd weighing $1.13 \mathrm{~g}$ has been identified from Square C Spit 2. Externally it has a glossy black glaze (Munsell 5YR 2/1) and has a very dark grey body and internal surface (N 3/-). The body is a stoneware harder than quartz with small, sparse inclusions that include dark and (rarer) light-coloured specks. It is decorated with a vertically aligned mat impression. With its lack of a curved surface and thickness of merely $4.8 \mathrm{~mm}$, the sherd is likely to be from a box. It may be from a Qing black monochrome, in view of the achievements of Chinese potters in producing 'mirror black' wares with a tinge of red in the glaze during the late seventeenth and early eighteenth centuries ( $\mathrm{Li} 2010)$.

Two tradeware sherds, almost certainly from the same vessel, were recovered from Square F Spit 1. Together they weigh $6.38 \mathrm{~g}$, and probably come from near the base of a martavan, a large pottery jar used especially for domestic storage of water or food (Merriam-Webster 2018). Externally the rough, unglazed surface is very dark greyish brown (10YR 3/2) and internally there is a smooth and sheeny, dark brown glaze (7.5YR 3/2). The body, which is a stoneware softer than iron, is black (10YR 2/1). Sharp-edged white grains (perhaps quartz) dominate the inclusions, along with occasional gleaming black specks. The best match is the Brittleware that is particularly a feature of the ceramics from the sixteenth century Brunei capital of Kota Baru (Harrisson 1990). However, this specimen may date to a later time. 


\section{Stone artefacts}

The aim of the lithics analysis was to describe the morphology of flakes, cores and debris and examine flaking strategies and investigate why flaked lithic material occurs in the Vasino fort site- a post-tradeware context. A central aim of this analysis was to test the model that flaked lithic artefacts were associated with strike-a-light activities, where siliceous stone flakes are marginally retouched, usually with metal implements, for the sole purpose of creating sparks for fire lighting (e.g. Glover and Ellen 1975:52-53). Flaked lithic artefacts used as strike-a-lights have been observed elsewhere in the region from similar archaeological contexts, after regional trade networks were importing metal goods (Brumm 2006; Bulbeck and Caldwell 2000:23, 32; Glover 1986:202; Glover and Ellen 1975; Lape et al. this volume; Scheans et al. 1970:180; Skertchly 1890:450, 451).

Analysis of stone artefacts at Vasino followed the methods outlined in Maloney (2011). In order to ensure accurate identification of flaked lithic artefacts, in an archaeological assemblage of post-tradeware and metal goods where lithic artefacts were superficially unexpected, diagnostic attributes that recognise controlled human blows were recorded. This methodology was applied to lithic assemblages from the Aru Islands by Hiscock (2007:211), where attributes were recorded that evidenced culturally modified lithic materials as anomalous in their reconstructed geomorphic context (Bryan and Schnurrenberger 1985:139). A set of nominal variables were employed following Hiscock (2007:211). Variables included the presence of a striking platform, bulb of percussion, negative flake scars, external initiation and flake termination; in combination, these support artefact identification. To identify strike-a-light technology, a set of variables outlined in O'Connor et al. (Chapter 2, this volume) were followed, based on observations of this practice throughout Island Southeast Asia (Brumm 2006; Glover 1986:202; Glover and Ellen 1975; Scheans et al. 1970:180; Skertchly 1890:450, 451). Variables include marginal concentrations of step fractures, crushing or cascading, bifacial battering, dense striations and typically minimal retouch before discard (Andrefsky 2009:196; Brumm 2006:169-170; Glover and Ellen 1975).

The stone artefact assemblage from Vasino is small (Table 4.4) and sparsely distributed throughout the deposit. A total of 74 flaked stone artefacts were recovered, including flakes, flaked pieces, retouched flakes and cores (Table 4.5). An additional four manuport sedimentary pebbles, exotic to the geomorphic context but without any modification, were recovered, as well as one small ground limestone piece.

Table 4.4. Vasino stone artefact assemblage.

\begin{tabular}{|l|c|c|c|c|c|c|c|c|}
\hline Spit & A & C & D & E & F & G & H & Total \\
\hline 1 & 1 & 5 & 1 & 1 & 0 & 5 & 16 & 29 \\
\hline 2 & 2 & 2 & 2 & 1 & 0 & 3 & 11 & 21 \\
\hline 3 & 0 & 0 & 4 & 0 & 3 & 0 & 9 & 16 \\
\hline 4 & 0 & 1 & 3 & 1 & 1 & 0 & 0 & 6 \\
\hline 5 & 0 & - & 0 & 0 & - & 0 & - & 0 \\
\hline 6 & 1 & - & 2 & 1 & - & 1 & - & 5 \\
\hline 7 & - & - & 2 & - & - & 0 & - & 2 \\
\hline 8 & - & - & 0 & - & - & - & - & 0 \\
\hline 9 & - & - & 1 & - & - & - & - & 1 \\
\hline 10 & - & - & 0 & - & - & - & - & 0 \\
\hline Total & 4 & 8 & 15 & 4 & 4 & 9 & 36 & 80 \\
\hline
\end{tabular}

Note: A dash indicates that the spit level was not excavated. Spits are not stratigraphically aligned (i.e. Spit A1 may be a different stratigraphic level than (1).

Source: Tim Maloney. 
Table 4.5. Vasino stone artefact types.

\begin{tabular}{|l|c|c|}
\hline Class & Count & Assemblage percentage \\
\hline Flake $(\times 10 \mathrm{~mm})$ & 19 & 24 \\
\hline Flake $(<10 \mathrm{~mm})$ & 4 & 5 \\
\hline Flaked piece & 22 & 28 \\
\hline Retouched flake & 12 & 15 \\
\hline Flake broken & 7 & 9 \\
\hline Manuport (pebble) & 4 & 5 \\
\hline Core single platform & 3 & 4 \\
\hline Core multiple platform & 2 & 3 \\
\hline Broken retouched flake & 2 & 3 \\
\hline Core bidirectional & 1 & 1 \\
\hline Primary flake & 1 & 1 \\
\hline Debitage flake & 1 & 1 \\
\hline Ground surface & 1 & 1 \\
\hline Total & 79 & 100 \\
\hline
\end{tabular}

Source: Tim Maloney.

Chert is the dominant raw material (90 per cent) and was reduced from small rounded nodules or cobbles with rounded and porous cortex. Chert nodules and cobbles are found close to Vasino. This material appears similar to those varieties described by Glover and Ellen (1975:55) and Glover (1986), used in strike-a-light industries, although, in contrast, flakes in the Vasino assemblage retained a higher frequency of cortex $(\mathrm{N}=33)$.

Fifty-five artefacts ( -70 per cent) displayed edge modification consistent with strike-a-light usewear (Table 4.6). These flakes are typically lightly retouched, with bifacial battering on isolated sections of the margins, and small step terminating scars with striations emerging from them $(\mathrm{N}=21)$.

Table 4.6. Vasino modification characteristics counts.

\begin{tabular}{|l|c|c|c|c|c|c|}
\hline Modification characteristic & $\begin{array}{c}\text { Edge modification } \\
\text { scars }\end{array}$ & $\begin{array}{c}\text { Bifacial } \\
\text { battering }\end{array}$ & $\begin{array}{c}\text { Step fracture } \\
\text { concentration }\end{array}$ & $\begin{array}{c}\text { Crushing } \\
\text { concentration }\end{array}$ & $\begin{array}{c}\text { Striations } \\
\text { parallel }\end{array}$ & $\begin{array}{c}\text { Striations } \\
\text { non-parallel }\end{array}$ \\
\hline Count & 55 & 34 & 47 & 24 & 18 & 21 \\
\hline Percentage of assemblage & 69.6 & 43.0 & 59.5 & 30.4 & 22.8 & 26.6 \\
\hline Percentage of modified flakes & 98.2 & 60.7 & 50.9 & 21.8 & 32.1 & 37.5 \\
\hline
\end{tabular}

Source: Tim Maloney.

This form of modification resembles existing descriptions of strike-a-light tools (see Chapter 2, this volume), where siliceous stone flakes were marginally retouched with metal implements to produce sparks for fire ignition (Brumm 2006; Glover 1986:202; Glover and Ellen 1975:5253; Scheans et al. 1970:180; Skertchly 1890:450, 451). From these observations we can expect marginal concentrations of step fractures, crushing or cascading, bifacial battering and dense striations to be a reasonable indicator of strike-a-light functions and use-wear (Andrefsky 2009:196; Brumm 2006:169-170; Glover and Ellen 1975). Results demonstrate that such characteristic variables occur on the majority of flakes in the assemblage (Table 4.6), with bifacial battering and step fracture concentrations being most prevalent. 


\section{The perforated discs}

Two ambiguous perforated discs were recovered, most likely either beads or spindle whorls. Disc 1 was excavated from Spit 2 in Square F, at a depth of $8 \mathrm{~cm}$ where it was found in association with large quantities of pottery. Disc 2 was excavated from Spit 3 in Square E at a depth of $20 \mathrm{~cm}$ along with large numbers of similar finds.

The material composition of both discs was tested with 10 per cent hydrochloric acid $(\mathrm{HCl})$. The reaction indicated that both artefacts were made from limestone. A further attribute analysis was conducted to establish function. As Table 4.7 indicates, Disc 1 measured $29 \mathrm{~mm}$ in diameter and was $5 \mathrm{~mm}$ in height. It weighed $2.8 \mathrm{~g}$. As it was less than half of its original size, its original weight was estimated to have been $5.9 \mathrm{~g}$. It was discoid in shape with raised sections on the upper surface around the central perforation. No use-wear marks were discernible on the central perforation. Disc 2 was also discoid in shape. It measured $21 \mathrm{~mm}$ in diameter and $10 \mathrm{~mm}$ in height. Its central perforation measured $2 \mathrm{~mm}$. It weighed $2.2 \mathrm{~g}$. Because it was broken and essentially half of its original size, its original weight was estimated to have been about $4.5 \mathrm{~g}$. No use-wear marks were discernible on the central perforation. Disc 2 was far more weathered than Disc 1.

Table 4.7. Vasino functional attributes of perforated discs.

\begin{tabular}{|l|l|l|l|l|l|l|l|l|}
\hline Item & Context & $\begin{array}{l}\text { Material } \\
\text { composition }\end{array}$ & Diameter $(\mathbf{m m})$ & Central perforation $(\mathbf{m m})$ & $\begin{array}{l}\text { Height } \\
(\mathbf{m m})\end{array}$ & Weight $(\mathbf{g})$ & Shape & Comments \\
\hline 1 & F2 & limestone & 21 & 2 & 10 & 2.2 & discoid & broken $1 / 2$ \\
\hline 2 & E1 & limestone & 29 & 8 & 5 & 2.8 & discoid & broken $<1 / 2$ \\
\hline
\end{tabular}

Source: Judith Cameron.

Both discs from Vasino were made from limestone. The material composition of artefacts is frequently indicative of function. Tools, for example, are usually made from more durable, common materials than ornaments, but some materials are ambiguous and in such cases identification is more complicated. Although stone is commonly used for beads, research into Southeast Asian spindle whorls indicates that, while pottery is the predominant material used for spindle whorls in the Southeast Asian archaeological record, stone spindle whorls have also been found in the region (Cameron 2013). However, the stone whorls that have been excavated from Neolithic sequences are much larger in size and heavier, being made to spin coarse, strong fibres. In terms of size, the Vasino discs lie just within the range of spindle whorls but they are also within the range of beads. The shape of the discs is more diagnostic. In India, for example, stone has been chosen for beads since the prehistoric period onwards, especially beads of the same shape as Disc 1. The size of central perforations is a more critical attribute. While the central perforation of Disc 2 lies within the range of spindle whorls, the central perforation of Disc 1 is far too narrow to take a spindle, the other component of the hand spindle. When these functional attributes are considered, with the absence of use-wear, the weight of evidence suggests that it is more likely that the discs from Vasino are beads rather than spinning tools.

\section{Vertebrate faunal remains}

This section is based on the full and detailed report of the Vasino vertebrate analysis by Amano and Piper (2011). A total of 3023 bone fragments were recovered from Vasino during the 2009 excavation. Of these, 1495 (49.5 per cent) were from Square D, 490 (16.2 per cent) from Square C, 377 (12.5 per cent) from Square G, 262 (8.7 per cent) from Square F, 212 (7 per cent) from Square E, 94 (3.1 per cent) from Square A, and 93 (3 per cent) were from Square $\mathrm{H}$ (Figure 4.14). No vertebrate remains were recovered from Square B. The bones tended to be 
slightly concentrated in Spits 3 and 4, especially in Square C, D and E, and in the subsurface layers in Squares F, G and H. Differential weathering of some skeletal elements, especially in Squares $\mathrm{C}$ and $\mathrm{D}$, suggests they have been subjected to little, if any, post-depositional reworking since their burial.

All vertebrate remains collected from the 2009 excavations of Vasino were examined in this study. The maximum lengths of all fragments greater than $5 \mathrm{~mm}$ were measured, unless they showed evidence of modern breakage, to identify any spatial and temporal variability in fragment size that might provide information on taphonomic process. Taphonomic terminology follows Piper (2003), modified from Lyman (1994). Important taphonomic and anthropogenic alterations, including weathering, burning, dog gnawing and butchery marks were recorded, and the location and orientation of human-derived bone modifications (e.g. cut and chop marks) were recorded in detail.

Distinctive vertebrate elements were identified to family, genus or species using the modern comparative reference collection and digital database housed at the Archaeological Studies Program, University of the Philippines. The criteria used for the biometric analyses of post-cranial elements follow von den Dreisch (1976). Whenever applicable, alternative measurements from diagnostic anatomical locales were used. Features that might indicate defects, for instance bone regrowth/pathologies, were also recorded. All teeth, bones with key taphonomic and anthropic modifications and other selective elements were photographed and stored in the university digital archive using a Nikon Coolpix Digital camera. Micrographs (microscopy images) were also taken and archived using the same camera mounted on a Nikon C-LEDS stereomicroscope.

For caprine and suid teeth, a standard measurement for the length of the tooth was taken, and the width of each molar column measured. All measurements were taken at, or as close to, the base of the enamel as possible. Since goat and pig teeth change shape as they wear, this location provides a point of reference where the analyst can be confident that all measurements of archaeological and comparative specimens will be comparable. To compensate for inter-analyst preferences, the lengths of the pig M1s and M2s were also measured at the occlusal surface (Piper and Amano 2011: Tables 5 and 6) so that they can be compared irrespective of which measurement has been used by other specialists. Pig ageing from molar eruption and post-cranial fusion follows Bull and Payne (1982), and molar wear scales are based on those presented by Grant (1982).

Table 4.8. Vasino number of individual specimens (NISP) of vertebrate taxa recovered.

\begin{tabular}{|l|l|l|l|l|l|}
\hline Class & Order & Family & Taxon & Common name & NISP \\
\hline \multirow{2}{*}{$\begin{array}{l}\text { Teleostei } \\
\text { (Infraclass) }\end{array}$} & & & & Bony fish & 11 \\
\cline { 2 - 6 } & Perciformes & Serranidae & Serranidae & Grouper & 1 \\
\hline \multirow{4}{*}{ Reptilia } & Squamata & Serpentes (Suborder) & Serpentes & Snake & 1 \\
\cline { 2 - 6 } & Testudines & Chelonioidea & Chelonioidea & Sea turtle & 1 \\
\hline & Mrimates & Cercopithecidae & Macaca fascicularis & Long-tailed macaque & 4 \\
\cline { 2 - 6 } & Carnivora & Canidae & Canis familiaris & Domestic dog & 8 \\
\cline { 2 - 6 } & Artiodactyla & Suidae & Sus sp(p). (domestic) & Domestic pig & 94 \\
\cline { 2 - 6 } & & Bovidae & Capra aegagrus hircus & Domestic goat & 87 \\
\cline { 2 - 6 } & & Bovidae & Bovinae (Subfamily) & Cattle/buffalo & 65 \\
\cline { 2 - 6 } & & Cervidae & Rusa cf. timorensis & Sunda sambar & 5 \\
\hline
\end{tabular}

Source: Noel Amano and Philip Piper. 


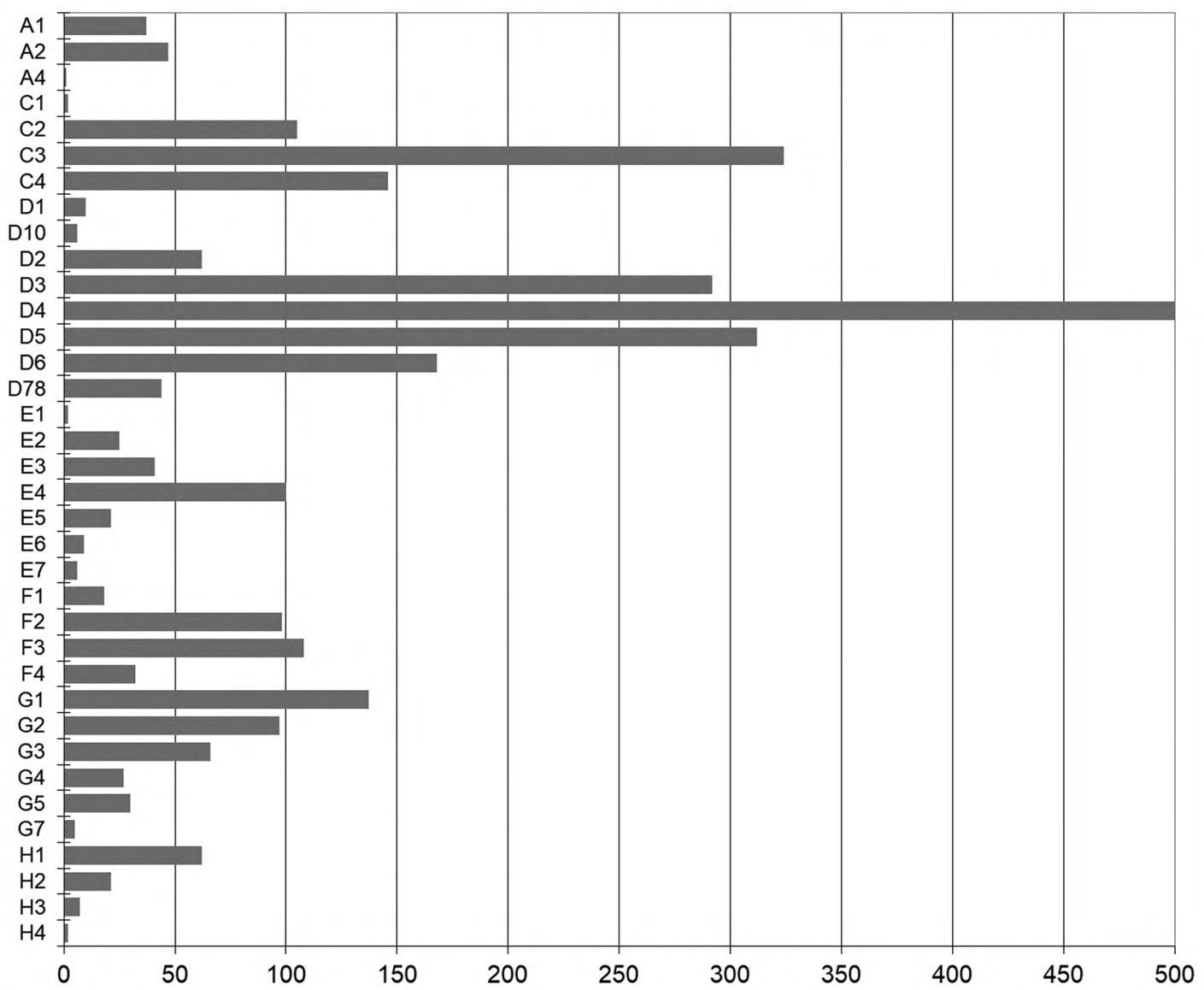

Figure 4.14. Vasino distribution of vertebrate remains Squares A-H (NISP).

Source: Noel Amano jr and Philip Piper.

The identification of the bone assemblage was severely limited by its fragmentary nature, and of the 2980 bones recovered, just 277 (9.3 per cent) bone fragments could be identified to family or a higher taxonomic level (Table 4.8).

Mammals account for 94.9 per cent $(\mathrm{N}=263)$ of all the identified vertebrate remains, with a few fish $(\mathrm{N}=12 ; 0.4$ per cent $)$ and reptile $(\mathrm{N}=2 ; 0.07$ per cent) bones also recovered. More than 77 per cent of the identified remains were recovered from Squares $\mathrm{C}$ and D. The mammal remains in Vasino were dominated by pig, goat and large bovine, cattle or buffalo. No differences in the frequencies of the three major taxa could be discerned through time at Vasino.

Human teeth were recorded from Square G, including two incisors from Spit 2, and an upper molar from Spit 4.

In total, five fragments of deer were recorded throughout the archaeological sequences, all from the D Square, the lowest at Spit 5. The remains are most likely to be from the Javan Rusa (Rusa timorensis), which is the only deer species introduced to Timor.

It was not possible to distinguish whether the 65 fragmentary bovine remains represented in the archaeological record belonged to either the genus Bos or Bubalus. The significance of this is discussed below. The majority of these remains were teeth (32.3 per cent), followed by ribs (18.5 per cent) and vertebral fragments (12.3 per cent). Ageing data are scarce for bovines, but the evidence from teeth and post-cranial remains suggests that they were probably from relatively young individuals of less than 28-32 months of age (Silver 1970). 
In total, 94 fragments of pig (Sus sp(p).) were recovered, the majority of which consisted of loose teeth. The results indicate that majority of the specimens (mandibular or maxillary) recovered did not exceed 18-22 months of age at death, with most probably slaughtered within the first 12-18 months of life (Bull and Payne 1982; Habermehl 1975). The age profile established from the dentition is supported by a number of unfused post-cranial elements recovered.

Eighty-seven fragments of caprine bone were recovered from Vasino from the topsoil (G1) to the lowest levels in Square D Spit 6. Although the remains of sheep and goats are difficult to distinguish in the archaeological record, the domestic goat (Capra aegagrus hircus) is the only taxon to be introduced into Island Southeast Asia (discussed below) until very recently (Fenner et al. 2017), and all the caprine remains from Vasino are considered to come from this taxon. Teeth were the most common goat remains recovered (37.9 per cent considering complete elements and 57.5 per cent including fragments).

Hillson (2005) noted that there is considerable variation in the eruption timing of the teeth of different domestic goat breeds, but the moderately to heavily worn nature of the M1s and M2s, and worn M3s, in the Vasino collection would suggest that several individuals probably exceeded 24 months in age at death (Moran and O'Connor 1994). Records of at least two dp4s and lightly worn M1s indicates the additional presence of some subadult individuals. Overall, the dental analysis of the Vasino caprine assemblage suggests goats from a relatively young age to quite old were being slaughtered on the site. The predominantly fused postcranial elements support the age profile derived from the dentition and indicate that the majority of goats were probably kept for at least two years before they were slaughtered.

It is not possible to distinguish with any absolute certainty in the Vasino assemblage whether the pig species represented is the domestic Eurasian wild boar (Sus scrofa) or the Sulawesi warty pig (Sus celebensis), a translocated wild species present on Timor (i.e. Clason 1986), or a hybrid of both. However, comparisons of tooth measurements with Sus scrofa specimens from Mainland Asia suggest that the specimens from Vasino show considerable size diminution over their wild progenitors. The measurements are also significantly smaller compared to those from Sus celebensis. The predominance of juvenile and subadult pigs in combination with size reduction is a good indication that the pigs from Vasino represent a managed, domestic population.

A total of eight dog bones from at least two individuals (based on two right mandibular M3s) were recorded.

Reptiles were represented by just two bone fragments: a single sea turtle phalanx recovered from Square G Spit 3, and a snake vertebra recorded in Square E Spit 2.

Twelve fish bones were recorded. The elements included several cranial fragments and a few vertebra and spines. Only one element was identified to the family level, a left maxillary fragment from a grouper (Serranidae) in Square D Spit 6.

\section{Invertebrate faunal remains}

Shells and shell fragments were identified to the lowest possible taxonomic level, using the Archaeology and Natural History (ANU) reference collection, in conjunction with a range of literary sources, including Cernohorsky $(1972,1978)$ and Hinton (1972). An attempt at identification was made for every shell fragment and no suppositions of 'edibility' of species were imposed during analysis (following Szabó 2009:186). In order to avoid inaccuracy, the dominant species within each sample was not assumed where a shell fragment only possessed the morphology definitive for genus level. 
The shell assemblages were quantified by weight ( $\mathrm{g}$ ), minimum number of individuals (MNI) and number of identified specimens present (NISP). MNI was calculated by the same repetitive feature throughout the Vasino assemblage; the posterior valve for chitons, apices for gastropods, and for bivalves both left and right hinges were counted, with the greater number selected for each square (following Szabó 2009:187). It should be noted that while Turbo sp. and Nerita sp. opercula were quantified during laboratory analysis, opercula counts are excluded from all aggregative calculations presented (Whitau 2011) to avoid inflating representation of the Turbidae and Neritidae families. The condition of shells and shell fragments, including evidence of artefact manufacture if any, was also noted during quantification.

Weight, MNI and NISP were all employed as each quantification method has its own inherent bias. Larger, denser molluscs, such as Tridacna sp., rank high on a comparative weight scale, although there are fewer individual fragments. Smaller shells of lower density, particularly Melanoides sp., which is a freshwater gastropod, tend to sit on the lower rungs of a comparative weight scale, even though it is the most dominant taxon in terms of both MNI and NISP. The cultural transformations that create and distort the assemblage can also create biases, particularly where the repetitive element selected for MNI counts is concerned. In the Vasino mollusc assemblage, although Trochidae was among the most dominant taxa in terms of weight and even NISP, it had very low MNI counts. This is because the apices were the repetitive element for all gastropods, and very few examples of the Trochidae family were uncovered with their spires intact. This bias is probably produced by people removing the spire of Trochus and Tectus species to extract the flesh for consumption.

The total shell weight from the Vasino assemblage was $6453.77 \mathrm{~g}$. Of this, the marine shell weight was $4795.29 \mathrm{~g}$ and the terrestrial gastropod weight was $1658.48 \mathrm{~g}$ (Table 4.9). A total of 58 taxa (excluding opercula) were identified. By weight, Turbo bruneus and the Turbinidae were the most dominant taxon and family group, respectively. The top five species by weight were, in declining order: Turbo bruneus, Hippopus hippopus, Clypeomorus batillariaeformis, Tridacna crocea and Cypraea sp. (Table 4.9; Figure 4.15). The top family groups by weight, in declining order, were: Turbinidae, Cardiidae, Tegulidae, Arcidae and Neritidae. By MNI and NISP counts, Melanoides sp. and Thiaridae were the most dominant taxon and family group respectively. The total MNI was 1159 (Table 4.10). The top five taxa by MNI count were, in declining order: Melanoides sp., Clypeomorus batillariaeformis, Turbo bruneus, Nerita albicilla and Cypraea sp. (see Table 4.10; Figure 4.15). The top five family groups by MNI count were, in declining order: Thiaridae, Potamididae, Turbinidae, Neritidae and Arcidae. The total NISP was 2329. The top five taxa by NISP count were, in declining order: Melanoides sp., Turbo bruneus, Chiton sp., Clypeomorus batillariaeformis and Pollia fumosa. The top five family groups by NISP count were, in declining order: Thiaridae, Turbinidae, Tegulidae, Potamididae and Chitonidae. However, the dominance of Melanoides sp. in Square $\mathrm{H}$ means that it is over-represented in the Vasino excavations as a whole. If Square H is excluded, Turbo bruneus and Clypeomorus batillariaeformis become the dominant taxa by NISP. 
Table 4.9. Vasino top 10 shell taxa by weight (g).

\begin{tabular}{|c|c|c|c|c|c|c|c|c|c|c|c|}
\hline Square & Spit & $\begin{array}{c}\text { Turbo } \\
\text { bruneus }\end{array}$ & $\begin{array}{l}\text { Hippopus } \\
\text { hippopus }\end{array}$ & $\begin{array}{c}\text { Clypeomorus } \\
\text { batillariaeformis }\end{array}$ & $\begin{array}{c}\text { Tridacna } \\
\text { crocea }\end{array}$ & $\begin{array}{c}\text { Cypraea } \\
\text { sp. }\end{array}$ & $\begin{array}{c}\text { Conus } \\
\text { sp. }\end{array}$ & $\begin{array}{c}\text { Nerita } \\
\text { albicilla }\end{array}$ & $\begin{array}{l}\text { Rochia } \\
\text { nilotica }\end{array}$ & $\begin{array}{c}\text { Strombus } \\
\text { sp. }\end{array}$ & Thiaridae \\
\hline A & 1 & 26.60 & 2.60 & - & 2.20 & \begin{tabular}{|l|}
3.22 \\
\end{tabular} & - & - & - & - & - \\
\hline A & 2 & 2.84 & 2.60 & - & - & 1.54 & - & - & - & - & - \\
\hline A & 3 & 10.08 & - & 18.30 & 3.26 & - & 1.70 & 7.68 & - & - & 0.88 \\
\hline A & 4 & 30.81 & 18.95 & 89.50 & 3.14 & - & 5.90 & 54.04 & - & - & 1.89 \\
\hline A & 5 & 7.32 & - & 5.16 & 5.83 & - & - & 23.82 & - & - & 1.25 \\
\hline A & 6 & - & - & - & - & - & - & - & - & - & 0.50 \\
\hline$C$ & 1 & 19.53 & - & - & - & - & - & - & - & - & - \\
\hline C & 2 & 40.13 & - & 5.25 & 1.39 & 10.08 & 0.37 & - & - & - & - \\
\hline$C$ & 3 & 62.40 & - & 7.13 & - & 4.72 & 14.98 & - & 19.07 & - & - \\
\hline C & 4 & 20.36 & - & 8.06 & - & 1.25 & 11.41 & - & - & - & - \\
\hline D & 1 & - & - & - & 6.98 & - & 1.66 & - & - & - & - \\
\hline D & 2 & 32.25 & - & 8.22 & - & 2.20 & 0.70 & - & - & - & - \\
\hline D & 3 & 40.00 & - & 13.40 & 13.81 & 3.02 & 17.80 & - & - & - & - \\
\hline D & 4 & 110.90 & - & 11.97 & 0.80 & 3.91 & - & - & 1.58 & 3.83 & - \\
\hline D & 5 & 73.73 & - & - & - & 13.05 & 2.10 & - & 16.45 & 68.47 & - \\
\hline$D$ & 6 & 36.22 & 41.79 & 25.13 & 44.44 & 5.10 & 13.11 & 5.01 & 5.24 & 19.65 & - \\
\hline D & 7 & 4.40 & 51.43 & - & - & 0.20 & - & - & - & 1.35 & - \\
\hline D & 8 & - & - & 2.84 & - & 6.46 & - & 2.17 & - & - & - \\
\hline D & 9 & - & - & 1.50 & - & - & - & 0.80 & - & - & 0.58 \\
\hline $\mathrm{E}$ & 1 & 2.12 & - & - & - & - & 2.49 & - & - & - & - \\
\hline $\mathrm{E}$ & 2 & 8.38 & - & - & 0.88 & 7.78 & 12.50 & - & - & - & - \\
\hline$E$ & 3 & 6.52 & - & - & - & - & 30.05 & 2.09 & - & - & - \\
\hline$E$ & 4 & 15.99 & - & - & - & 6.13 & - & 1.92 & - & 2.92 & 0.35 \\
\hline$E$ & 5 & - & - & - & - & 0.85 & - & 7.53 & - & - & 1.24 \\
\hline$E$ & 6 & - & - & - & - & - & - & 2.91 & - & - & 1.75 \\
\hline$E$ & 7 & 25.80 & 2.60 & - & 0.20 & 3.22 & - & - & - & - & - \\
\hline $\mathrm{F}$ & 1 & - & - & - & - & - & - & - & - & - & - \\
\hline $\mathrm{F}$ & 2 & 24.87 & 7.94 & - & - & 4.47 & - & - & - & 18.61 & \\
\hline $\mathrm{F}$ & 3 & 32.57 & - & - & - & 20.69 & - & - & - & 7.14 & 0.96 \\
\hline $\mathrm{F}$ & 4 & 2.07 & - & 2.83 & - & - & - & - & - & - & 0.25 \\
\hline G & 1 & 9.93 & - & - & - & 16.72 & 13.12 & - & 19.70 & - & - \\
\hline G & 2 & 49.77 & - & - & 9.96 & 22.90 & 1.61 & - & - & - & 1.58 \\
\hline G & 3 & 20.08 & 43.44 & - & 28.94 & 24.95 & 1.57 & - & - & - & - \\
\hline G & 4 & 18.39 & 23.32 & - & - & 6.51 & 4.36 & - & - & - & - \\
\hline G & 5 & 19.96 & - & - & - & - & - & 7.96 & - & - & - \\
\hline G & 6 & - & - & - & - & - & - & 31.68 & - & - & 7.50 \\
\hline G & 7 & - & - & - & - & - & - & - & - & - & 3.12 \\
\hline $\mathrm{H}$ & 1 & 13.70 & 8.99 & - & 3.36 & 2.14 & - & 6.60 & - & - & 23.90 \\
\hline $\mathrm{H}$ & 2 & 25.57 & 5.50 & - & 35.83 & 2.86 & 18.22 & 3.80 & 13.76 & - & 34.40 \\
\hline $\mathrm{H}$ & 3 & 27.74 & 79.62 & 1.00 & 24.10 & 5.43 & 22.98 & 12.79 & 64.10 & 6.87 & 34.22 \\
\hline $\mathrm{H}$ & 4 & 2.92 & - & - & - & - & - & - & - & - & 9.65 \\
\hline \multicolumn{2}{|l|}{ Total } & 823.95 & 288.78 & 200.29 & 185.12 & 179.40 & 176.63 & 170.80 & 139.90 & 128.84 & 124.02 \\
\hline
\end{tabular}

Source: Mirani Litster. 
90 Forts and Fortification in Wallacea

Table 4.10. Vasino top 10 shell taxa by MNI.

\begin{tabular}{|c|c|c|c|c|c|c|c|c|c|c|c|c|c|}
\hline Square & Spit & 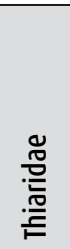 & 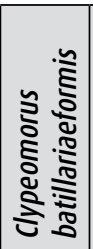 & 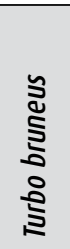 & 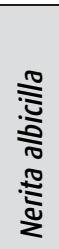 & 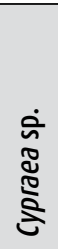 & 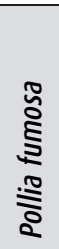 & 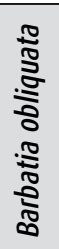 & $\underset{\stackrel{\dot{n}}{\mathbf{s}}}{\stackrel{\Xi}{\mathbf{s}}}$ & 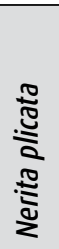 & 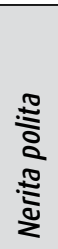 & 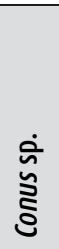 & 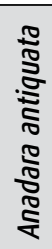 \\
\hline$A$ & 1 & - & - & 5 & - & $<1$ & 6 & - & - & - & - & - & 1 \\
\hline$A$ & 2 & - & - & 1 & - & $<1$ & $<1$ & 1 & $<1$ & - & - & - & $<1$ \\
\hline$A$ & 3 & 2 & 15 & 2 & 3 & - & 2 & - & $<1$ & - & - & 1 & - \\
\hline$A$ & 4 & 7 & 75 & 8 & 21 & - & $<1$ & - & $<1$ & 3 & 6 & 1 & - \\
\hline$A$ & 5 & 3 & 4 & $<1$ & 7 & - & - & - & $<1$ & - & 1 & - & - \\
\hline$A$ & 6 & 1 & - & - & - & - & - & - & - & - & - & - & - \\
\hline$C$ & 1 & - & - & 2 & - & - & - & - & - & - & - & - & - \\
\hline$C$ & 2 & - & 4 & 6 & - & 2 & 1 & $<1$ & 1 & - & - & $<1$ & $<1$ \\
\hline C & 3 & - & 5 & 11 & - & $<1$ & $<1$ & 1 & - & - & 1 & $<1$ & $<1$ \\
\hline$C$ & 4 & - & 5 & 2 & - & 1 & $<1$ & 2 & - & - & - & $<1$ & 1 \\
\hline$D$ & 1 & - & - & - & - & - & - & - & - & - & - & $<1$ & - \\
\hline$D$ & 2 & - & 5 & 4 & - & 1 & 1 & - & - & - & - & $<1$ & - \\
\hline$D$ & 3 & - & 7 & 7 & - & 2 & 2 & 1 & 1 & - & $<1$ & 1 & 1 \\
\hline$D$ & 4 & - & 10 & 15 & - & 3 & 3 & 3 & 1 & - & 1 & - & 1 \\
\hline$D$ & 5 & - & - & 9 & - & 3 & 1 & 3 & - & 1 & 1 & 2 & 2 \\
\hline$D$ & 6 & - & 18 & 2 & 2 & $<1$ & 1 & 4 & - & 3 & 1 & 2 & 1 \\
\hline$D$ & 7 & - & - & 1 & - & $<1$ & - & 1 & - & - & - & - & - \\
\hline$D$ & 8 & - & 2 & - & 1 & 1 & - & 1 & - & - & - & - & - \\
\hline$D$ & 9 & 1 & 1 & - & 1 & - & - & - & - & 1 & 1 & - & 1 \\
\hline$E$ & 1 & - & - & 1 & - & - & $<1$ & - & - & - & - & $<1$ & - \\
\hline$E$ & 2 & - & - & 1 & - & 1 & - & 2 & $<1$ & - & - & $<1$ & 1 \\
\hline$E$ & 3 & - & - & 1 & 1 & - & - & 2 & - & - & - & 1 & - \\
\hline$E$ & 4 & 1 & - & 1 & 1 & 3 & $<1$ & 1 & $<1$ & - & - & - & 1 \\
\hline$E$ & 5 & 3 & - & - & 3 & $<1$ & 1 & - & - & - & - & - & - \\
\hline$E$ & 6 & 2 & - & - & 1 & - & - & - & $<1$ & - & - & - & - \\
\hline$E$ & 7 & - & - & 5 & - & 1 & 8 & - & - & - & - & - & 1 \\
\hline$F$ & 1 & - & - & - & - & - & - & $<1$ & - & - & - & - & - \\
\hline$F$ & 2 & - & - & 4 & - & 1 & 1 & 1 & - & - & $<1$ & - & $<1$ \\
\hline$F$ & 3 & 4 & - & 4 & - & 5 & 1 & 1 & $<1$ & 1 & - & - & - \\
\hline $\mathrm{F}$ & 4 & 1 & 2 & 1 & - & - & - & - & - & - & - & - & - \\
\hline $\mathrm{G}$ & 1 & - & - & 2 & - & 3 & $<1$ & $<1$ & $<1$ & - & - & 1 & $<1$ \\
\hline $\mathrm{G}$ & 2 & 2 & - & 4 & - & 3 & $<1$ & 3 & - & - & - & $<1$ & - \\
\hline $\mathrm{G}$ & 3 & - & - & 2 & - & 7 & 2 & 2 & - & - & - & $<1$ & - \\
\hline $\mathrm{G}$ & 4 & - & - & 1 & - & 2 & - & $<1$ & - & - & - & 1 & - \\
\hline $\mathrm{G}$ & 5 & - & - & 3 & 3 & - & - & - & - & - & - & - & - \\
\hline $\bar{G}$ & 6 & 26 & - & - & 11 & - & - & - & - & - & - & - & - \\
\hline $\bar{G}$ & 7 & 4 & - & - & - & - & - & - & - & - & - & - & - \\
\hline $\mathrm{H}$ & 1 & 71 & - & 5 & 2 & 1 & 1 & 1 & 7 & - & $<1$ & - & - \\
\hline $\mathrm{H}$ & 2 & 111 & - & 6 & 1 & $<1$ & $<1$ & 1 & 11 & 2 & $<1$ & 2 & - \\
\hline $\mathrm{H}$ & 3 & 113 & $<1$ & 4 & 4 & 1 & $<1$ & - & 6 & $<1$ & 2 & 1 & - \\
\hline $\mathrm{H}$ & 4 & 24 & - & 1 & - & - & - & - & 1 & $<1$ & - & - & - \\
\hline \multicolumn{2}{|l|}{ Total } & 376 & 153 & 121 & 62 & 41 & 31 & 31 & 28 & 11 & 14 & 13 & 11 \\
\hline
\end{tabular}

Source: Mirani Litster. 
As the heavy weight of some of the marine shells skewed the results, MNI was used for interpretation. The majority of identified taxa were lower intertidal species associated with rocky reef, which can be accessed $2 \mathrm{~km}$ north of Vasino. Two taxa (Nerita planospira and Geloina sp.) are associated with mangrove forests, one taxon (Thiaridae) with freshwater environments and seven taxa (Patella sp., Nerita plicata, Nerita sp., Cerithium sp., Cerithidea sp., Arcidae, Ungulinidae and Gafrarium sp.) with mixed habitat zones (Figure 4.16). Terrestrial gastropod counts were also included, as proportions of land snails can sometimes reflect periods of lower occupation density.

The assemblage provides little evidence for shell artefact manufacture. With the exception of heavily reduced Nautilus sp. fragments, there is only one convincing example of shell reduction, a Turbo chrysostomus shell from Square G Spit 3. This particular T. chrysostomus is mostly whole, with only the outer lip missing from the mouth. A hole in the shape of an irregular trapezoid has been cut from the body whorl. This irregular shape, coupled with reduction marks on the anterior surface, clearly point towards human production likely to remove the flesh, since gastropod predation, which is initiated from the posterior surface, leaves a perfectly circular hole.

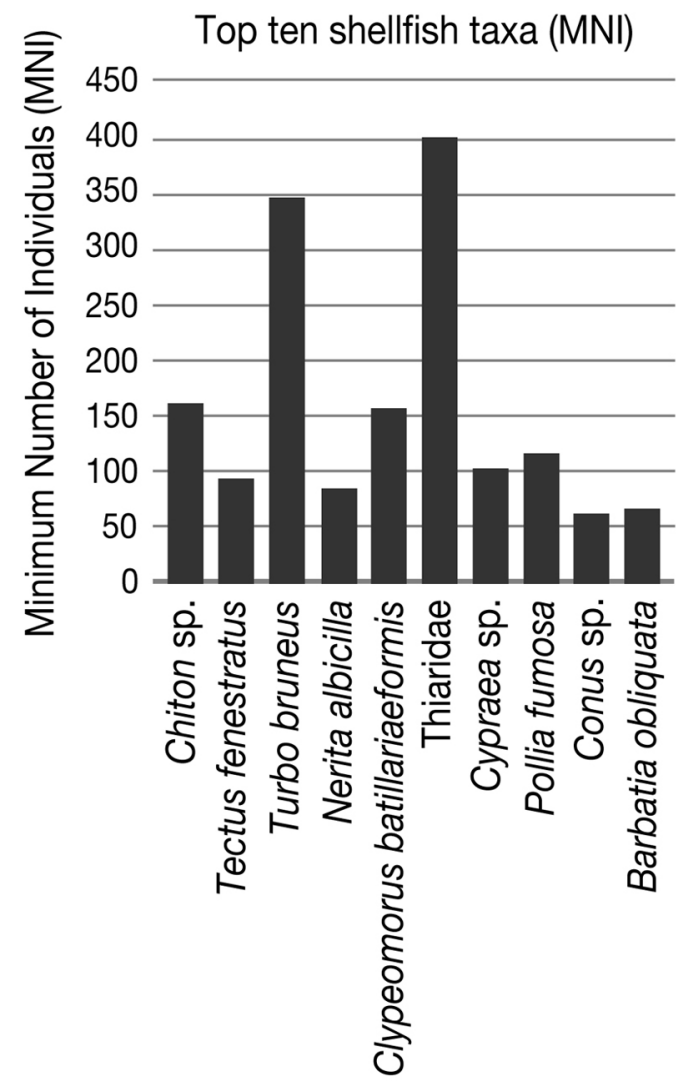

Taxon
Top ten shellfish taxa (g)

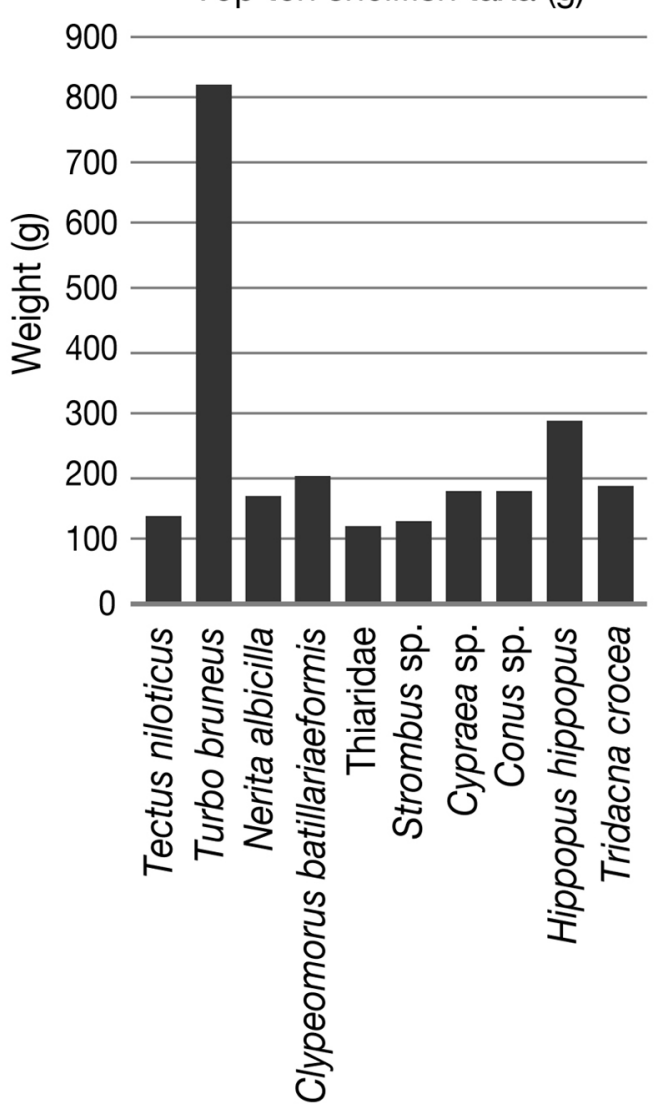

Taxon

Figure 4.15. Vasino top 10 shell taxa by MNI and weight (g).

Source: CartoGIS ANU. 


\section{Vasino all squares}
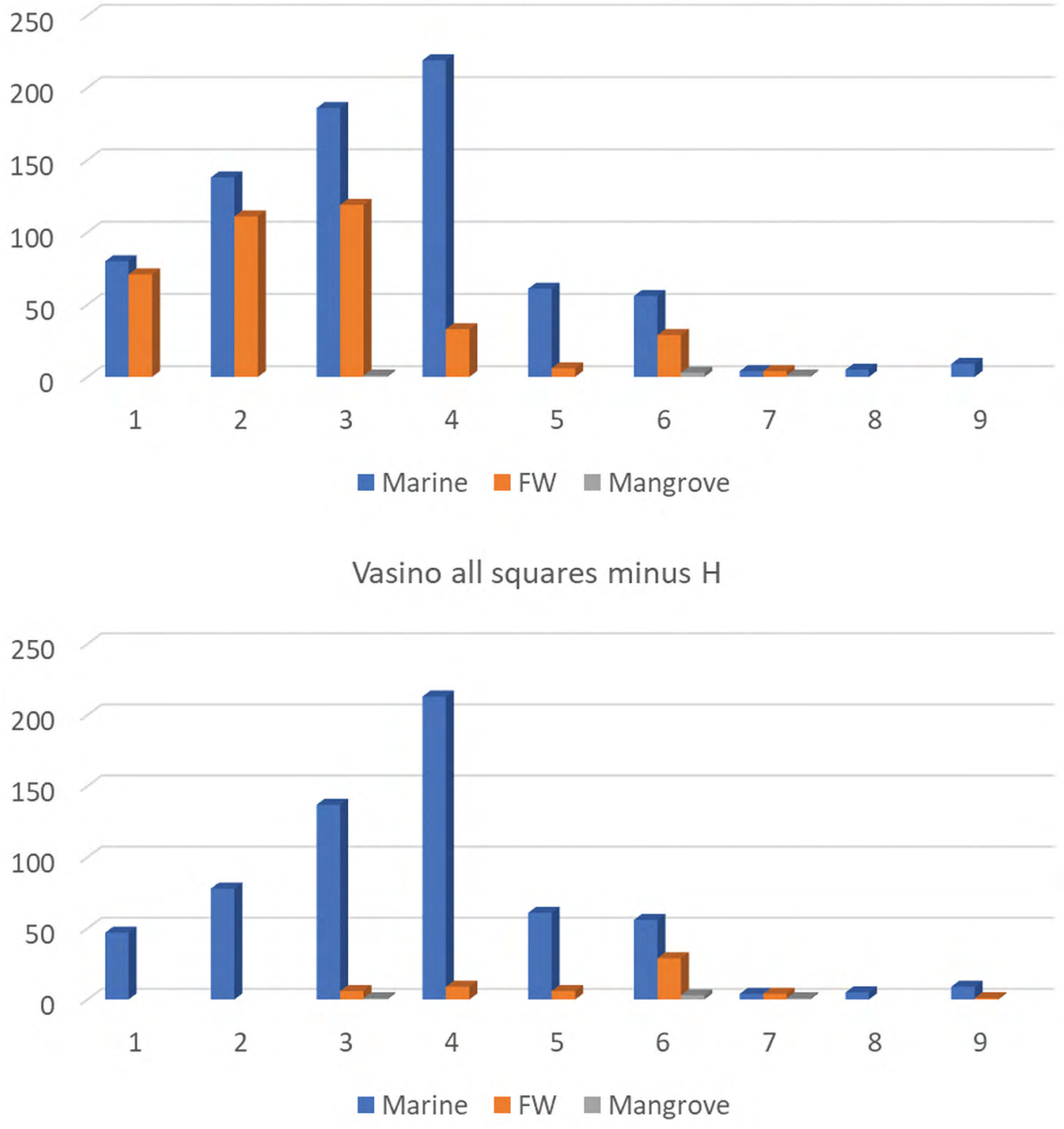

Figure 4.16. Vasino shellfish habitat by MNI (FW=Freshwater).

Source: Rose Whitau.

\section{Discussion}

The Vasino earthenware assemblage is dominated by jars with everted rims of diameter generally varying between 11 and $18 \mathrm{~cm}$ and rounded bodies. These earthenware vessels have a form suitable for use as cooking pots but direct evidence for such use (in the form of carbonised accretions) is minimal. Larger jars and covered jars may have been used for storage. The majority of vessels were apparently formed using the paddle-and-anvil technique and finished on a slow wheel. There is considerable variability in jar rim form, which may be related to the three separate manufacturing locales, as suggested by the three temper types identified from petrological analysis, although any matching exercise between temper type and vessel form has not been possible. Around 7 per cent of the identifiable vessels appear to have been serving vessels, including a distinctive group of dark 
red burnished bowls of up to $30 \mathrm{~cm}$ rim diameter. Around 6 per cent of the assemblage shows signs of decoration, mainly vertical paddle-impressed designs but including a small number of sherds with painted dots and curvilinear motifs. No wasters were found, therefore we conclude that all pottery has been brought into the site. Unlike the site of Macapainara at Ili Vale near the port of Com (see Chapter 2, this volume) there is minimal tradeware (and no glass or metals).

There were few formal artefact types, apart from a small quantity of strike-a-light flints. We conclude that the two limestone perforated discs are most probably beads similar to ones recorded prehistorically in India. Generally, those associated with elites are hard stone forms rather than that represented at Vasino. The softer limestone is relatively simpler to work with a small knife. There was little shell artefact manufacture, except for heavily reduced Nautilus sp. fragments, and only one convincing example of shell reduction, a Turbo chrysostomus shell.

During excavation, rodent burrows and other disturbances were recorded in Squares A and D, and along with inversions in the radiocarbon dates within different stratigraphic horizons we suggest that the spatial and temporal integrity of archaeological materials recovered from these squares has been compromised (Jack Fenner pers. comm. 2011). Analysis of the bone assemblages suggests that only minimal reworking might have occurred to the majority of the faunal remains, but the authors suggest that the chronological results presented here for the presence and absence of particular taxa within these squares should be treated with some caution. Nevertheless, the initial occurrence of the major identified taxa in Square D (pig, Bovinae and goat) is supported by their early fifteenth-century $\mathrm{AD}$ presence in other squares and spits, strengthening the interpretive results of this study (see below for details). It is intriguing to note that Squares C and $\mathrm{D}$ are located close to the most sacred places at Vasino, according to local informants: the tei and the graves of ancestors. The bone assemblage was certainly densest at this location and it is possible that this could have been the location of animal sacrifices in the past. Even in 2009, it was at this location that the local inhabitants chose to sacrifice animals in a ceremony to close the excavations (Jack Fenner pers. comm. 2011).

The complete absence of some wild animals, such as the northern common cuscus (Phalanger orientalis) and common palm civet (Paradoxurus hermaphroditus), and the scarcity of deer, macaque, turtle and snake suggests that hunting did not play a major role in the diet of the inhabitants of Vasino and they relied more heavily on domestic animals. This could be a result of restricted movement due to the need for security, although it is obvious that people had to leave the fort to fetch water, garden and collect shellfish.

The vertebrate faunal remains indicate that the inhabitants of Vasino primarily maintained populations of domestic pigs, goats and probably cattle throughout the fifteenth to seventeenth centuries $\mathrm{AD}$, although the faunal analysis was unable to determine whether the bovine remains were of corralled domestic stock or hunted feral animals (Amano and Piper 2011:27). The present subsistence strategy of maintaining herds of pigs dominated by juveniles and subadults and herds of goats and bovines is a relatively good analogy for the economy of the inhabitants of Vasino. Sue O'Connor (pers. comm. 2011) reported that contemporary human communities in Timor-Leste maintain herds of goats up to 50 individuals that range freely during the day under the watchful eye of a shepherd and are penned at night. Individual households possess perhaps one or two sows and several individuals, ranging from piglets to young adults. Large herds of cattle and buffaloes are also seen and these are often owned by the community. This description fits relatively well with the zooarchaeological evidence and suggests these systems of animal management are perhaps of some antiquity.

Cattle or buffaloes are recorded throughout the archaeological sequence at Vasino. Glover (1986) placed the introduction of Bovinae to Timor at around $1500 \mathrm{BP}$, but this is very uncertain and concrete evidence for the remains of introduced cattle across Island Southeast Asia is rare. 
Van den Bergh et al. (2009) report that diagnostic remains of cattle (presumably Bos or Bubalus) were only recovered from the upper $50 \mathrm{~cm}$ of deposit at Liang Bua cave on Flores and correspond to dates within the last 500 years. They argued that Bovinae were probably introduced by the Portuguese to Flores. The new records from Vasino indicate that cattle were also present in Timor by the fourteenth or fifteenth century AD. The dates, the complete absence of glass and the almost complete absence of tradeware from Vasino also suggest that the introduction of cattle to Timor likely predates European contact. It was not possible to build up a confident age profile for the Bovinae from Vasino and it is therefore not possible to determine whether the remains are those of corralled domestic stock or hunted feral animals (Amano and Piper 2011:27). However historic accounts mention the dependence of Timorese on water buffaloes as work animals, particularly for rice agriculture (cf. Dampier 1703). There are also historical records of feral buffalo being hunted on Timor. For example, William Dampier (1703: 170), who visited the north coast of Timor in 1699, noted: 'Their plantations are very mean; for they delight most in hunting; and here wild buffaloes and hogs enough, though very shy, because of their so frequent hunting'.

The archaeological research at Vasino has clearly demonstrated that goats were present in Timor by the early to mid-fifteenth century AD (Fenner et al. 2017). Zooarchaeological records of goat are scarce throughout Mainland and Island Southeast Asia, and the exact origins and timing for the introduction of the goat to Island Southeast Asia remains unresolved (Amano and Piper 2011). Capral Ovis appears in the zooarchaeological record of China at 4000 cal. BP but only in small numbers (Jing and Flad 2002) and no goat bones as early as this have yet been recorded in Neolithic sites in the Philippines, Vietnam (e.g. Piper et al. 2009, 2010) or Thailand (Kijngam 2011). A recent study of animal bones from the Batanes Islands in the northern Philippines recorded goat in deposits postdating the earlier half of the first millennium $\mathrm{AD}$, and the goat seems to succeed some of the earliest evidence for the introduction of Chinese porcelain on the islands (Piper et al. 2013). Patterns of long-distance Chinese trade began to emerge in the latter part of the first millennium $\mathrm{BC}$ and early centuries $\mathrm{AD}$ and then intensified towards the midlate first millennium $\mathrm{AD}$, and this latter period appears to coincide with the first appearance of the goat on the Batanes Islands. In Indonesia, Morwood et al. (2008:1785, Table 2a) recorded a single Capridae bone in Spit 21 at Song Gupuh in eastern Java slightly above a $\mathrm{C}^{14}$ date of $2180 \pm 120$ cal. BP (WK14648). This latter identification needs further verification. However, the earliest securely dated goats in the Indonesian archipelago are from Bali, probably imported from South Asia, and dated to c. $200 \mathrm{cal}$. BC. Isotopic analyses indicated that these early goats in Bali had likely been imported from South Asia and possibly represented some of the earliest introduced caprines to the Southeast Asian region (Fenner et al. 2017).

In Timor itself, Glover (1986: 205) reported that Capra/Ovis remains first appear in the archaeological sequence in the cave of Uai Bobo 2, in Horizon VII (5000-6000 BP) and Horizon IX (3500-4000 BP). These dates for goat on Timor are almost certainly too old. An explanation for these early records of goat on Timor might be that a common contemporary use of caves is for goat herding pens (Sue O'Connor pers. comm. 2010). This practice is possibly of some antiquity and caused considerable disturbance and reworking of goat bones into old deposits. Glover (1986:205) did, however, also note that goat bones were only recovered in quantity at Uai Bobo 1 Horizon V and at Uai Bobo 2 in Horizon X, which are dated to about 1400-1800 and 2000-2500 BP respectively. This is a much more realistic timing for the presence of goat on Timor (Amano and Piper 2011). The dates for the presence of goats from Vasino fit neatly with the fifteenth and sixteenth-century AD accounts of Antonio Pigafetta, the chronicler of Magellan who noted that: 'In [Timor], and nowhere else, is found white sandalwood, besides ginger, swine, goats, rice ... wax, and other things, and parrots of divers sorts and colours' (1969:141). 
Pig bones were recovered throughout the archaeological sequences at Vasino. The age profile of the pigs suggests that these are more likely to be domestic stock maintained around the fortified site rather than hunted animals. Glover (1986:197) has argued that in his excavations the pig was consistently the earliest introduced animal to Timor, between 5000 and $4000 \mathrm{cal}$. BP. A recent review by Piper (2017) has demonstrated that pig introduction to Island Southeast Asia was more likely to have been between 3500 and 4000 BP.

The presence of bones with dog gnawing and digestion indicate that dogs likely roamed freely around the site (Amano and Piper 2011). The relative scarcity of dog bones and the absence of butchered dog bone leave the question of dogs in the diet of Timorese open to further research, but recent studies into Neolithic subsistence in southern Vietnam (Piper et al. 2014, 2017) and the northern Philippines (Piper et al. 2013) have confirmed that dogs were eaten during antiquity in Island Southeast Asia. Glover (1986) found two canines in his excavation of Bui Ceri Uato in Timor that morphometrically fall outside the range of those of typical Melanesian and Southeast Asian dogs. He also found a mandible that has a 'groove' in the lingual side of the canine alveolus 'which is characteristic of the dingo but not of the Melanesian dog' (1986:205). The teeth recovered from Vasino fall within the size range of those of modern-day Southeast Asian dogs (from the measurements of at least 43 individuals). Also, alveolar distances in the mandible recovered from Square D Spit 6 were not significantly different from those of native Philippine dogs kept in the University of the Philippines Archaeological Studies Program Zooarchaeology collection. It is possible that the remains reported by Glover (1986) represent a different population from the Vasino dogs. Currently, the oldest known canid remains on Timor are from a dog burial excavated from the cave Matja Kuru 2 and directly dated to 2967 \pm 50 BP (uncalibrated; WK-10051) suggesting a long history of domestic dogs on the island (Veth et al. 2005).

The absence of murid remains in the assemblage is also notable. Giant rats have been reported in pre-Neolithic layers in Timor (Hawkins et al. 2017a, 2017b; Veth et al. 2005). Aplin (2010) recovered the remains of several giant rats from caves in Timor-Leste, one identified as a new species of the genus Coryphomys dated to 1000 years BP. In his excavation of four cave sites in Timor-Leste (Lie Siri, Bui Ceri Uato, Uai Bobo 1 and Uia Bobo 2), Glover (1986) recovered more than 90,000 murid bones, mostly from Rattus exulans and Melomys. The location of Vasino on a hilltop and its intensive occupation by people could account for the rarity in endemic murid remains (though commensal taxa might be expected), and the presence of scavenging dogs could also have influenced preservation. It is also possible that many of the large endemic species were extinct before the development of the Vasino fortification in the fourteenth-fifteenth centuries AD.

Very few fish bones were recovered, which at face value might imply that fish and fishing played a very minor role in the diet of the inhabitants of Vasino. However, Piper et al. (2009) have argued that the presence of free-ranging dogs could have a severe impact on the preservation of fish bone in archaeological sites. For example, Jones $(1984,1986)$ found that between 85 per cent and 100 per cent of identifiable fish bone elements were lost when skeletons were fed to dogs. These experiments demonstrate just how easily fish bones are digested by dogs and this could render fishing as part of the subsistence strategy almost invisible in the archaeological record.

The majority of identified shellfish taxa were intertidal species associated with rocky reef, one taxon (Thiaridae) from freshwater environments, a small quantity from mangrove forests and seven taxa associated with mixed habitat zones (Figure 4.16). Terrestrial gastropods were also present. The presence of these species indicates exploitation of inshore marine, estuarine and freshwater habitats all found nearby today. Surprisingly, even large species such as Tridacna and Hippopus were carried inland to the upland settlement. Optimal foraging literature suggests

\section{terira australlis 53}


that such large species will be harvested and the shell discarded on the reef (Bird et al. 2002, 2004). However the clam shell is quite reduced and it is possible it was brought back to be used for manufacturing shell artefacts rather than for the meat content, although no shell artefacts were found.

\section{Conclusion}

The Bayesian analysis indicates that the initial occupation of Vasino most likely falls in the second half of the fourteenth century. The implications of this chronology for the beginning date and drivers of fortifications in Timor are discussed in McWilliam (Chapter 6, this volume; c.f. also Fenner and Bulbeck 2013; O'Connor et al. 2012). Only one radiocarbon date related directly to the start of fortifications at Vasino. As it is more than 250 years later than the overall site occupation date, it would, if used alone, indicate that fortifications started much later than previously suggested. The naturally defensive position of the site, however, suggests that defence from attack was a consideration from the initial start of occupation, and that this single date may well relate to reworking or extension of the site perimeter wall along the laca rather than to the initial start of fortifications. Local informants estimate that the site has been abandoned for the last 200 years (Andrew McWilliam pers. comm. 2009). The archaeology appears to endorse this information as the top spits were virtually sterile of artefacts and dominated by land snail.

The overall impression of the society living at Vasino, in the 500-odd years that it was occupied from the mid-fourteenth century, is that the people had a lifestyle not dissimilar from that of Timorese subsistence farmers today and in the recent past, tending domestic animals and gardens within a similar environment (McWilliam and Traube 2011). However, unlike their modern-day counterparts, they conducted little or no hunting or fishing, with wild resource exploitation limited to some shellfish gathering. Vasino society during the time frame recorded by the excavations appears to be rather insular, albeit with some limited outside contact (pottery was brought in), but virtually no trade items, such as tradeware and glass, unlike their neighbours at Macapainara during the same time frame (Chapter 2, this volume). The lack of tradeware suggests that the inhabitants were focused on domestic activities and did not engage in trade with outsiders, unlike the inhabitants of Macapainara or Leki Wakik (see Chapters 2 and 5). This may be due to the fact that there was no good harbour near to Vasino. However, this isolation, limited movement and lack of hunting for wild animals may also be the result of the necessity for security. The position of Vasino on a hilltop and the construction of its massive fortified walls indicate that the inhabitants faced some kind of aggressive threat, the likely nature of and reasons for which are explored in McWilliam (Chapter 6, this volume).

\section{References}

Amano, N. and P.J. Piper 2011. A report on the animal remains from the 2009 archaeological excavation at Vasino in East Timor. Unpublished report. The Australian National University, Canberra. hdl.handle. net/1885/111565. Accessed 19 March 2020.

Andrefsky, W. 2009. The analysis of stone tool procurement, production and maintenance. Journal of Archaeological Research 17: 65-103. doi.org/10.1007/s10814-008-9026-2.

Aplin, K. 2010. Quaternary murid rodents of Timor part I: New material of Coryphomys buehleri Schaub, 1937, and description of a second species of the genus. Bulletin of the American Museum of Natural History 341:1-80. doi.org/10.1206/692.1. 
Bird, D.W., J.L. Richardson, P.M. Veth and A.J. Barham 2002. Explaining shellfish variability in middens on the Meriam Islands, Torres Strait Australia. Journal of Archaeological Science 29:457-469. doi.org/10.1006/jasc.2001.0734.

Bird, D.W., R. Bliege Bird and J.L. Richardson 2004. Meriam ethnoarchaeology: Shellfishing and shellmiddens. Memoirs of the Queensland Museum, Cultural Heritage Series 3(1):183-197.

Brumm, A. 2006. Fire-making using a stone 'strike-a-light' in the Soa Basin of Flores, Indonesia. Bulletin of the Indo-Pacific Prehistory Association 26:168-170.

Bryan, A.L. and D. Schnurrenberger 1985. A contribution to the study of the naturefact/artifact controversy. In M.G. Plew, J.C. Woods and M.G. Pavesic (eds), Stone tool analysis: Essays in honor of Don E. Crabtree, pp. 133-159. University of New Mexico Press, Albuquerque.

Buck, C., G. Boden, A. Christen and G. James 1999. BCal online radiocarbon analysis tool. bcal.shef.ac.uk. Accessed 14 February 2018. doi.org/10.11141/ia.7.1.

Bulbeck, D. 2011. Vasino earthenware pottery. Unpublished report to the Department of Archaeology and Natural History, The Australian National University, Canberra. (Available from the author.)

Bulbeck, D. 2012. Tradeware and glass sherds, and beads and other ornaments excavated at Macapainara and Vasino, East Timor, in 2008. Unpublished report to the Department of Archaeology and Natural History, The Australian National University, Canberra. (Available from the author.)

Bulbeck, D. and I. Caldwell. 2000. Land of iron: The historical archaeology of Luwu and the Cenrana Valley. Results of the Origin of Complex Society in South Sulawesi Project (OXIS). Centre for South-East Asian Studies, University of Hull, Hull.

Bull, G. and S. Payne 1982. Tooth eruption and epiphysial fusion in pigs and wild boar. In B. Wilson, C. Grigson and S. Payne (eds), Ageing and sexing animal bones from archaeological sites, pp. 55-71. British Series 109. British Archaeological Reports, Oxford.

Cameron, J. 2013. The spinning tools from Sunget, Anaro and Savidug. In P. Bellwood and E. Dizon (eds), 4000 years of migration and cultural exchange: The archaeology of the Batanes Islands, Northern Philippines, pp. 115-121. Terra Australis 40. ANU E Press, Canberra. doi.org/10.22459/ta40.12.2013.07.

Cernohorsky, W.O. 1972. Marine shells of the Pacific II. Pacific Publications, Sydney.

Cernohorsky, W.O. 1978. Tropical Pacific marine shells. Pacific Publications, Sydney.

Clason, A.T. 1986. The faunal remains of Paso in Northern Sulawesi, Indonesia. In Proceedings of the International Congress of Zooarchaeology, pp. 35-62. La Pensée Sauvage, Grenoble.

Dampier, W. 1703. A new voyage round the world; describing particularly, the Isthmus of America, several coasts and islands in the West Indies, the Isles of Cape Verd, the passage by Terra del Fuego, the South Sea Coasts of Chile, Peru, and Mexico, the Isle of Guam, one of the Ladrones, Mindanao and other Philippine and East India Islands near Cambodia, China, Formosa, Luconia, Celebes etc., and New Holland, Sumatra, Nicobar Isles, the Cape of Good Hope, and Santa Hellena: Their soil, rivers, harbours, plants, fruits, animals, and inhabitants: their customs, religion, government, trade etc. Volume 1. Knapton, London. doi.org/10.5962/ bhl.title.135457.

Dickinson, W. 2011. Petrological report on pottery from East Timor. Unpublished report. Department of Archaeology and Natural History, The Australian National University, Canberra.

Fenner, J.N. and D. Bulbeck 2013. Two clocks: A comparison of ceramic and radiocarbon dates at Macapainara, East Timor. Asian Perspectives 52(1):143-156. doi.org/10.1353/asi.2013.0005. 
Fenner, J.N., R.K. Jones, P.J. Piper, M. Llewellin, M.K. Gagan, B. Prasetyo and A. Calo 2017. Early goats in Bali, Indonesia: Stable isotope analyses of diet and movement. The Journal of Island and Coastal Archaeology 13(4):563-581. doi.org/10.1080/15564894.2017.1325421.

Frasché, D.F. 1976. Southeast Asian ceramics, ninth through seventeenth centuries. The Asia Society, Washington D.C.

Glover, I. 1986. Archaeology in Eastern Timor, 1966-67. Terra Australis 11. Department of Prehistory, Research School of Pacific Studies, The Australian National University, Canberra.

Glover, I. and R.F. Ellen 1975. Ethnographic and archaeological aspects of a flaked stone collection from Seram, Eastern Indonesia. Asian Perspectives 18(1):51-60.

Grant, A. 1982. The use of tooth wear as a guide to the age of domestic ungulates. In B. Wilson, C. Grigson and S. Payne (eds), Ageing and sexing animal bones from archaeological sites, pp. 91-108. British Series 109. British Archaeological Reports, Oxford.

Guy, J.S. 1986. Oriental trade ceramics in South-East Asia: Ninth to sixteenth centuries. Oxford University Press, Oxford.

Habermehl, K.H. 1975. Die Alterbestimmung bei Hausund Labortieren. Paul Parey, Berlin.

Habu, J., P. Lape and J. Olsen 2017. The handbook of East and South East Asian archaeology. Springer Ebook, New York. doi.org/10.1007/978-1-4939-6521-2.

Harrisson, B. 1990. Pusaka: Heirloom jars of Borneo. Oxford University Press, Oxford.

Harrisson, B. 1995. Later ceramics in South-East Asia: Sixteenth to twentieth centuries. Oxford University Press, Oxford.

Hawkins, S., S. O’Connor, T. Maloney, M. Litster, S. Kealy, J. Fenner, K. Aplin, C. Boulanger, S. Brockwell, R. Willan, E. Piotto and J. Louys 2017a. Oldest human occupation of Wallacea at Laili Cave, Timor-Leste, shows broad-spectrum foraging responses to late Pleistocene environments. Quaternary Science Reviews 171:58-72. doi.org/10.1016/j.quascirev.2017.07.008.

Hawkins, S., S. Samper Carro, J. Louys, K. Aplin, S. O’Connor and Mahirta 2017b. Human palaeoecological interactions and owl roosting at Tron Bon Lei, Alor Island, Eastern Indonesia. The Journal of Island and Coastal Archaeology 13(3):371-387. doi.org/10.1080/15564894.2017. 1285834.

Hinton, A. 1972. Shells of New Guinea and the central Indo-Pacific. Jacaranda Press, Port Moresby.

Hiscock, P. 2007. Artefacts on Aru: Evaluating the technological sequences. In S. O'Connor, M. Spriggs and P. Veth (eds), The archaeology of the Aru Islands, Eastern Indonesia, pp. 205-234. Terra Australis 22. ANU Press, Canberra. doi.org/10.22459/ta22.2007.10.

Jing, Y. and R.K. Flad 2002. Pig domestication in ancient China. Antiquity 76:724-732. doi.org/10.1017/ s0003598x00091171.

Jones, A.K.G. 1984. Some effects of the mammalian digestive system on fish bones. In N. Desse-Berset (ed.) Second Fish Osteoarchaeology Meeting, Paris: Centre National de la Recherche Scientifique, pp. 61-65. Monographies Techniques 16. Centre de Recherches Archeologiques, Paris.

Jones, A.K.G. 1986. Fish bone survival in the digestive systems of pig, dog and man. In D. Brinkhuizen and A. Clason (eds), Fish and archaeology, pp. 53-61. International Series 294. British Archaeological Reports, Oxford.

Kijngam, A. 2011. The mammalian fauna. In C.F.W. Higham and A. Kijngam (eds), The origins of the civilization of Angkor. Volume IV: The excavation of Ban Non Wat: The Neolithic occupation, pp. 189-196. The Fine Arts Department, Bangkok. 
Li, J. 2010. Qing dynasty ceramics. In L. Zhiyan, V.L. Bower and H. Li (eds), Chinese ceramics from the Palaeolithic period through the Qing Dynasty, pp. 459-533. Yale University Press, New Haven. doi.org/ 10.1353/cri.2012.0038.

Lyman, R.L. 1994. Vertebrate taphonomy. Cambridge University Press, Cambridge.

Maloney, T. 2011. Stone artefacts of Macapainara and Vasino, Timor-Leste. Unpublished report. Department of Archaeology and Natural History, College of Asia and the Pacific, The Australian National University, Canberra.

McCormac, F.G., A.G. Hogg, P.G. Blackwell, C.E. Buck, T.F.G. Higham and P.J. Reimer 2004. Shcal04 Southern Hemisphere Calibration, 0-11.0 Cal Kyr BP. Radiocarbon 46(3):1087-1092. doi.org/ $10.1017 / s 0033822200033014$.

McWilliam, A.R. and E.G. Traube (eds) 2011. Land and life in Timor-Leste: Ethnographic essays. ANU E Press, Canberra. doi.org/10.22459/1ltl.12.2011.

McWilliam, A., D. Bulbeck, S. Brockwell and S. O'Connor 2012. The cultural legacy of Makassar stone in East Timor. The Asia Pacific Journal of Anthropology 13(3):262-279. doi.org/10.1080/14442213. 2012.674054 .

Merriam-Webster Dictionary 2018. Entry for 'martaban'. www.merriam-webster.com/dictionary/martaban. Accessed 25 July 2018.

Moran, N.C. and T.P. O’Connor 1994. Age attribution in domestic sheep by skeletal and dental maturation: A pilot study of available sources. International Journal of Osteoarchaeology 4:267-285. doi.org/10.1002/oa.1390040402.

Morwood, M.J., T. Sutikna, E.W. Saptomo, K.E. Westaway, Jatmiko, A.D. Rokus, M.W. Moore, D.Y. Yuniawati, P. Hadi, J.-X. Zhao, C.S.M. Turney, K. Fifield, H. Allen and R.P. Soejono 2008. Climate, people and faunal succession on Java, Indonesia: Evidence from Song Gupuh. Journal of Archaeological Science 35:1776-1789. doi.org/10.1016/j.jas.2007.11.025.

O'Connor, S., A. McWilliam, J.N. Fenner and S. Brockwell 2012. Examining the origin of fortifications in East Timor: Social and environmental factors. The Journal of Island and Coastal Archaeology 7(2):200-218. doi.org/10.1080/15564894.2011.619245.

Orton, C.R. and P.A. Tyers 1991. Counting broken objects: The statistics of ceramic assemblages. Proceedings of the British Academy 77:163-184.

Pigafetta, A. 1969. Magellan's voyage: A narrative account of the first circumnavigation. Yale University Press, New Haven and London.

Piper, P.J. 2003. Rodents, reptiles and amphibians: The palaeoecological and taphonomic study of small vertebrate remains from archaeological settlement sites. Unpublished PhD thesis. University of York, York.

Piper, P.J. 2017. The origins and arrival of the earliest domestic animals in Mainland and Island Southeast Asia: A developing story of complexity. In P. Piper, H. Matsumura and D. Bulbeck (eds), New perspectives in Southeast Asian and Pacific prehistory, pp. 251-272. Terra Australis 45. ANU Press, Canberra. doi.org/10.22459/ta45.03.2017.15.

Piper, P.J. and N. Amano 2011. A report on the animal remains from the 2008 excavations at Macapainara, East Timor. Unpublished report. The Australian National University, Canberra. hdl.handle.net/1885/ 111566. Accessed 19 March 2020.

Piper, P.J., F.Z. Campos and H.-C. Hung 2009. A study of the animal bone recovered from Pits 9 and 10 at the site of Nagsabaran in northern Luzon, Philippines. Hukay 14:47-90. 
Piper, P.J., F.Z. Campos, D.N. Kinh and N. Amano 2010. A report on the animal remains from the 2009 archaeological excavations at An Son, Duc Hoa, District, Vietnam. Unpublished report. University of the Philippines, Manila.

Piper, P.J., N. Amano, H.-Y. Yang and T.P. O’Connor 2013. The terrestrial vertebrate remains. In P. Bellwood and E. Dizon (eds), 4000 years of migration and cultural exchange: The archaeology of the Batanes Islands, Northern Philippines, pp. 169-199. Terra Australis 40. ANU Press, Canberra. doi.org/10.22459/ta40.12.2013.10.

Piper, P.J., F.Z. Campos, D.N. Kinh, N. Amano, M. Oxenham, B.C. Hoang, P. Bellwood and A. Willis 2014. Early evidence for pig and dog husbandry from the Neolithic site of An Son, Southern Vietnam. International Journal of Osteoarchaeology 24:68-78. doi.org/10.1002/oa.2226.

Piper, P.J., K.T.K Nguyen, T.K.Q. Tran, R. Wood, C.C. Castillo, A. Weisskopf, F. Campos, N.K. Dang, C. Sarjeant, A.S.B. Mijares, M. Oxenham and P. Bellwood 2017. The Neolithic settlement of Loc Giang on the Vam Co Dong River, southern Vietnam and its broader regional context. Archaeological Research in Asia 10:32-47. doi.org/10.1016/j.ara.2017.03.003.

Rye, O.S. 1981. Pottery technology: Principles and reconstruction. Taraxacum, Washington, D.C.

Santoso, S. 1995. Tradisi Gerabah di Indonesia dari Masa Prasejarah hingga Masa Kini. Himpunan Keramik Indonesia, Jakarta.

Scheans, D.J., K.L. Hutterer and R.L. Cherry 1970. A newly discovered blade tool industry from the central Philippines. Asian Perspectives 13:179-181.

Shepard, A.O. 1974. Ceramics for the archaeologist. Carnegie Institution Publications, Washington D.C.

Silver, I.A. 1970. The ageing of domestic animals. In D.R. Brothwell and E.S. Higgs (eds), Science in archaeology: A survey of progress and research, pp. 283-302. Praeger Printing, New York.

Skertchly, S.B.J. 1890. On fire-making in North Borneo. The Journal of the Anthropological Institute of Great Britain and Ireland 19:445-452. doi.org/10.2307/2842488.

Szabó, K. 2009. Molluscan remains from Fiji. In G. Clark and A. Anderson (eds), The early prehistory of Fiji, pp. 183-211. Terra Australis 31. ANU E Press, Canberra. doi.org/10.22459/ta31.12.2009.08.

van den Bergh, G., H. Meijer, R. Awe Due, M. Morwood, K. Szabó, L. van den Hoek Ostende, T. Sutikna, E. Saptomo, P. Piper and K. Dobney 2009. The Liang Bua faunal remains: A $95 \mathrm{kyr}$ sequence from Flores, East Indonesia. Journal of Human Evolution 57(5):527-537. doi.org/10.1016/ j.jhevol.2008.08.015.

Veth, P., S. O'Connor and M. Spriggs 2005. Continuity in tropical cave use: Examples from Timor-Leste and the Aru Islands, Maluku. Asian Perspectives 44(1):180-192. doi.org/10.1353/asi.2005.0015.

von den Driesch, A. 1976. A guide to the measurement of animal bones from archaeological sites. Bulletin No. 1. Peabody Museum of American Archaeology and Ethnology, Cambridge, Massachusetts. 
This text is taken from Forts and Fortification in Wallacea: Archaeological and Ethnohistoric Investigations, edited by Sue O'Connor, Andrew McWilliam and Sally Brockwell, published 2020 by ANU Press, The Australian National University, Canberra, Australia.

doi.org/10.22459/TA53.2020.04 